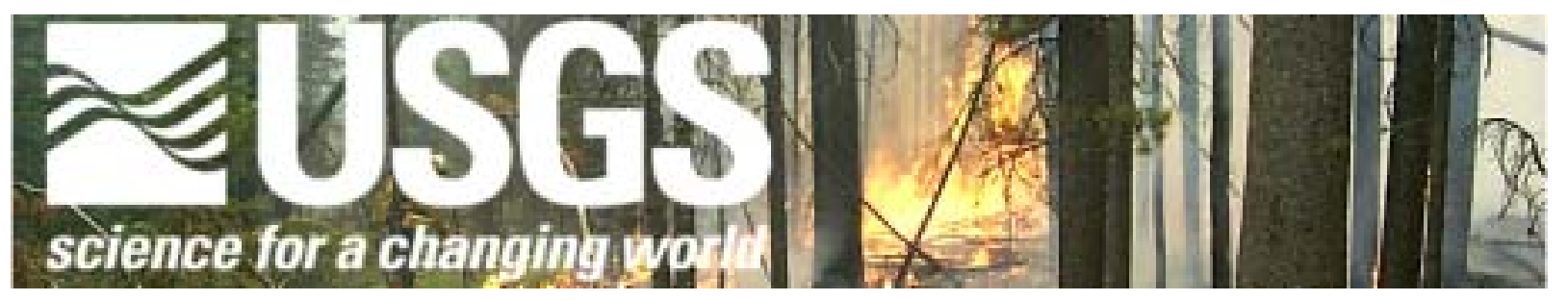

\title{
Geochemical data for stream sediment and surface water samples from Panther Creek, the Middle Fork of the Salmon River, and the Main Salmon River, collected before and after the Clear Creek, Little Pistol, and Shellrock wildfires of 2000 in central Idaho
}

\author{
by \\ Robert G. Eppinger ${ }^{1}$, Paul H. Briggs ${ }^{1}$, Betsy Rieffenberger ${ }^{2}$, Carol Van Dorn ${ }^{3}$, \\ Zoe Ann Brown', James G. Crock', Philip H. Hageman', Allen Meier', \\ Stephen J. Sutley ${ }^{1}$, Peter M. Theodorakos ${ }^{1}$, and Stephen A. Wilson ${ }^{1}$
}

Open-File Report

This report supercedes U.S. Geological Survey Open-File Report 01-0161

2003

This report is preliminary and has not been reviewed for conformity with U.S. Geological Survey (USGS) editorial standards nor with the North American Stratigraphic Code. Any use of trade, firm, or product names is for descriptive purposes only and does not imply endorsement by the U.S. Government. Although these data have been used by the USGS and have been successfully imported into data base programs, no warranty, expressed or implied, is made by the USGS as to how successfully or accurately the data can be imported into any specific application software running on any specific hardware platform. The fact of distribution shall not constitute any such warranty, and no responsibility is assumed by the USGS in connection therewith.

\section{U.S. DEPARTMENT OF THE INTERIOR}

U.S. GEOLOGICAL SURVEY

${ }^{1}$ U.S. Geological Survey, Denver, Colorado

${ }^{2}$ U.S. Forest Service, Salmon-Challis National Forest, Salmon, Idaho

${ }^{3}$ U.S. Forest Service, Santa Fe National Forest, Santa Fe, New Mexico 


\section{TABLE OF CONTENTS}

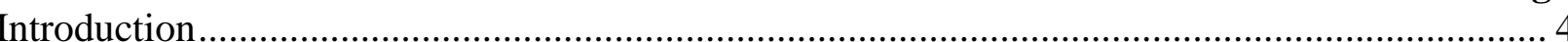

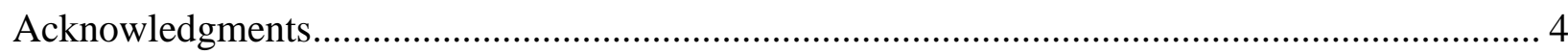

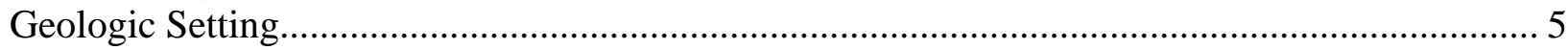

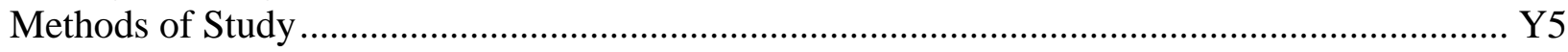

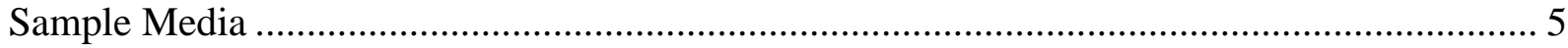

Sample Collection and Preparation............................................................................ 6

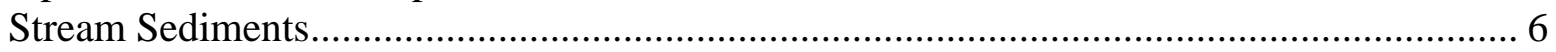

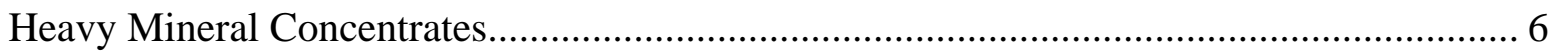

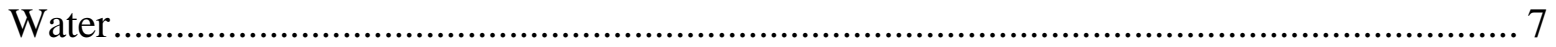

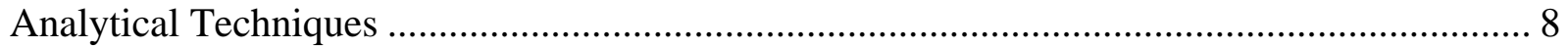

Techniques Used on Stream Sediment and Concentrate Samples .................................... 10

Inductively Coupled Plasma-Atomic Emission Spectrometry—Stream Sediments ........ 10

Atomic Absorption Spectrometry—Stream Sediments ............................................ 11

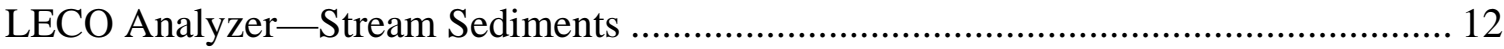

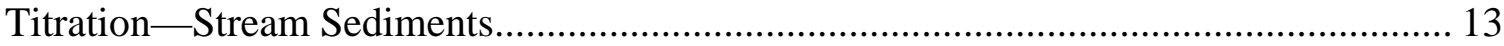

Coulometric Titration-Stream Sediments........................................................... 13

Semiquantitative Emission Spectrography_Concentrates ....................................... 13

Techniques Used on Water Samples...................................................................... 14

Inductively Coupled Plasma-Atomic Emission Spectrometry ................................... 14

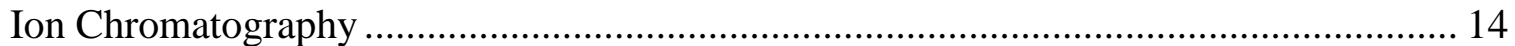

Inductively Coupled Plasma-Mass Spectrometry .................................................. 14

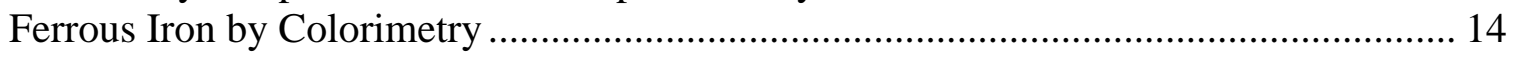

Mercury by Flow Injection-Cold Vapor-Atomic Fluorescence Spectrometry ................ 15

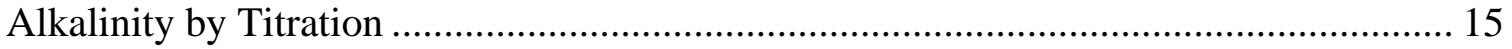

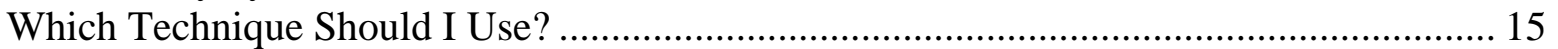

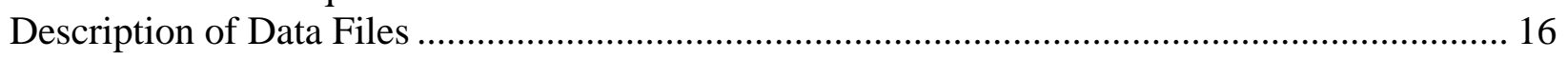

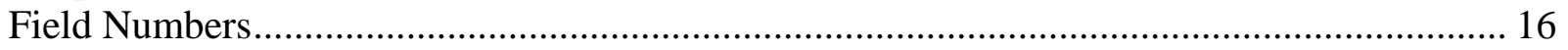

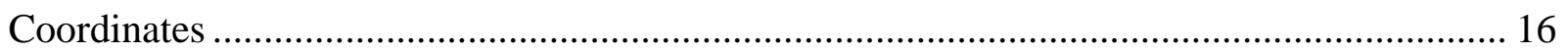

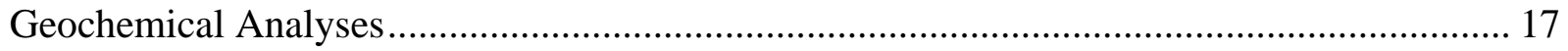

Descriptions of Tables and Fields within Tables.......................................................... 17

Tables containing sample and site descriptive information .......................................... 17

Tables containing geochemical analyses ................................................................. 19

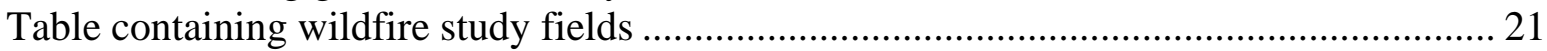

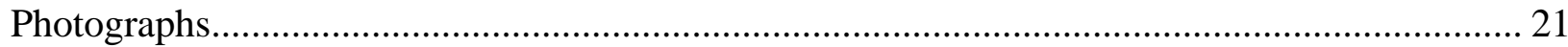

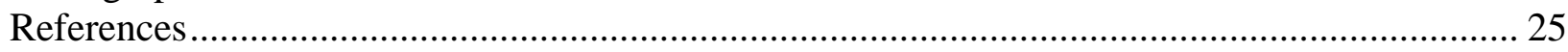

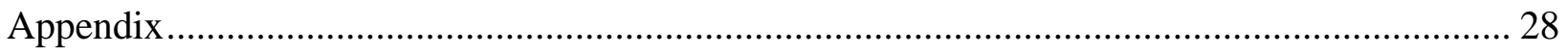




\section{LIST OF FIGURES}

Filename

Figure 1. Map showing location of study area in central Idaho..... .FIGURE1.PDF Figure 2. Sample site map for stream sediment and surface water samples collected from Panther Creek, the Middle Fork of the Salmon River, and the Main Salmon River. FIGURE2.PDF

\section{LIST OF TABLES}

Page

Table 1. Count of types of samples collected in this study .................................6

Table 2. Elements determined and analytical methods used for all sample media...............9

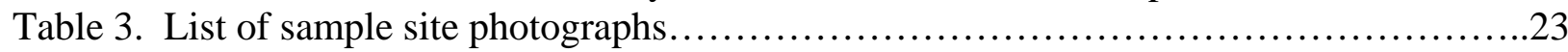

\section{LIST OF TABLES IN APPENDIX}

Table A1. Limits of determination for stream sediment samples analyzed by 40 -element Page inductively coupled plasma-atomic emission spectrometry, total extraction (ET) ................28 Table A2. Limits of determination for selected elements in stream sediment samples analyzed

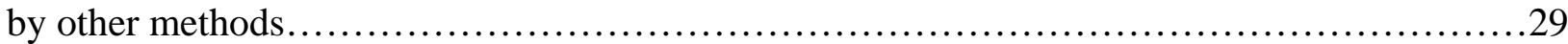
Table A3. Limits of determination for nonmagnetic heavy-mineral concentrate samples analyzed by semiquantitative emission spectrography (ES) ........................................ Table A4. Limits of determination for acidified water samples analyzed by inductively coupled

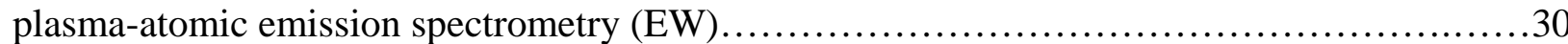
Table A5. Limits of determination for anions in water samples determined by ion chromatography (IC). ....

Table A6. Limits of determination for water samples analyzed by inductively coupled plasmamass spectrometry (MW) 


\section{INTRODUCTION}

During a 3-week period in the summer of 1996, the U.S. Geological Survey conducted a reconnaissance baseline geochemical study in central Idaho. Areas covered include Panther Creek, the Middle Fork of the Salmon River from Boundary Creek to the mouth, and the Main Salmon River from North Fork to Corn Creek (Fig. 1). Stream sediment samples were collected at all sample sites. Filtered and unfiltered stream water samples were collected at most sites.

The purpose of the baseline study was to establish a "geochemical snapshot" of the area, as a datum for monitoring future change in the geochemical landscape, whether natural or human-induced. Events that could change the geochemical landscape include, but are not limited to, mining, flood, landslide, wildfire, or resource extraction activities. Geochemical data for the 1996 baseline study were published in Eppinger and others (2001). Data in the present report includes and supercedes that released in Eppinger and others (2001).

In the summer of 2000, there were numerous large wildfires in central Idaho. In particular, the Clear Creek (206,000 acres; 83,370 hectares), Little Pistol (74,000 acres; 29,950 hectares), and Shellrock (64,000 acres; 25,900 hectares) fires swept across much of the area that was sampled. In 2001, ten months after the wildfires, the entire area was resampled by occupying and recollecting at the same sample sites initially sampled in 1996. This work was done and the request of the U.S. Forest Service, Salmon-Challis National Forest. Presented herein are the analytical data for both the 1996 pre-wildfire and 2001 post-wildfire sampling periods. Also presented are digital images of the 2001 post-wildfire sample sites.

For the initial 1996 study, sampling was conducted from July 8 through June 28. Weather during this period was warm and precipitation sparse. Only one rain event occurred during the sampling period - a brief rainstorm on the evening of July 16 , with about $1 / 4$ " $(0.64 \mathrm{~cm})$ of total precipitation. River levels were lower than normal for this time of year because of lower-thannormal precipitation during the previous winter and spring. In 2001, the sampling was conducted from June 7 through June 21, constrained by unusually low water conditions following an exceedingly dry winter and spring. Precipitation during the sampling period was negligible.

The study area lies within the Salmon River Mountains, and much of the areaparticularly along the Middle Fork of the Salmon River-lies within the Frank Church-River of No Return Wilderness (Fig. 1). Topographic relief is high. Peaks at the heads of drainages commonly have elevations above $9,000 \mathrm{ft}(2,740 \mathrm{~m})$, while river-level elevations are typically several thousand feet lower, ranging from around 5,700 $\mathrm{ft}(1,740 \mathrm{~m})$ at Boundary Creek on the Middle Fork of the Salmon River, to less than 3,000 ft (914 m) at Corn Creek on the Main Salmon River. Terrain ranges from rugged, steep peaks, ridges, and cirques at higher elevations, through tree-covered mountains and meadows at intermediate elevations, to steep, narrow, heavily vegetated canyons at lower elevations. Climatic conditions vary from warm summer days with frequent thunderstorms to cold winter days with heavy snowfall accumulations.

Access to the Panther Creek basin is by U.S. Forest Service gravel roads 030 from North Fork, Idaho, and 055, which runs along Panther Creek. Access to the Main Salmon River from North Fork to Corn Creek is by U.S. Highway 93 and U.S. Forest Service gravel road 030, which runs along the Main Salmon, ending at Corn Creek, and by raft or jet boat. Access to the Middle Fork of the Salmon River is exclusively by oar-powered raft or pack trail.

\section{ACKNOWLEDGMENTS}

We thank the staff of Salmon-Challis National Forest for access and logistical help. As volunteers in the U.S. Geological Survey Volunteers for Science Program, Sparky Easom, 
Maryellen Easom, Eugene Jansak, and Barbara Orr provided expert guide service, camp support, and aided in sample collection. The following U.S. Geological Survey personnel are thanked for field work assistance: Karl Evans, Karen Lund, Steven M. Smith, and Gary Winkler. Funding for the study was provided by the U.S. Geological Survey Mineral Resources Program and by the U.S. Forest Service, Salmon-Challis National Forest.

\section{GEOLOGIC SETTING}

Precambrian metamorphic rocks, the Late Cretaceous Idaho batholith, and Eocene plutons related to the Challis Volcanics are the predominant rock types in the study area. Faults in the area are mainly northeast and northwest trending.

The metamorphic rocks are principally quartzites and gneisses of the Precambrian Yellowjacket and Apple Creek Formations. Sporadic roof pendants and xenoliths of schist, quartzite, and calc-silicate rocks of uncertain Precambrian to Paleozoic age are found locally in close spatial association with the Idaho batholith.

The Idaho batholith varies from leucocratic granite to biotite granodiorite and hornblende-biotite granodiorite. It is typically salt-and-pepper gray in color and locally porphyritic with large microcline phenocrysts. The batholith is widespread in central Idaho, covering some 25,000 square miles $(64,700 \mathrm{sq} \mathrm{km})$.

Eocene plutons found in the study area are generally intermediate to granitic in composition and typically have an overall pink color, such as the large Casto Pluton, which crops out along portions of the Middle Fork of the Salmon River. These plutons are the crystalline, unerupted counterparts to the voluminous Challis Volcanics that are found in much of central Idaho.

\section{METHODS OF STUDY}

\section{SAMPLE MEDIA}

Geochemical sample media collected include stream-sediment, heavy-mineralconcentrate (1996 only), and water samples. The chemical composition of a stream-sediment sample is controlled primarily by the major geologic units within the drainage basin and to a lesser degree by metal-scavenging materials such as amorphous iron- and manganese oxides, clays, and organic matter. Minor elemental constituents within the stream sediment, such as elements related to mineral deposits within the drainage basin, may be detected in the sediment analysis, but commonly have a small overall influence on the sample because of dilution by barren material.

Since elements related to mineralized rocks are commonly found in heavy minerals, heavy-mineral-concentrate samples from stream sediment were also collected. Heavy-mineral concentrates provide chemical information about ore-related and rock-forming dense minerals, and permit chemical determination of some elements not easily detected in stream-sediment samples. Further, microscopic identification of nonmagnetic minerals in heavy-mineralconcentrate samples may provide additional useful mineralogical information. Heavy-mineral concentrate samples were collected only in the 1996 study

Water samples were collected from available natural water sources, principally from flowing streams and rivers, but also from hot springs. Mineral deposits rich in sulfide minerals (whether mined or unmined), solid waste from mine dumps and mill tailings derived from such deposits, and sulfide-rich rocks from areas of hydrothermally altered bedrock, are possible 
sources of acid and metal loading in the environment. Locally, hot springs and certain geologic units can contribute high concentrations of dissolved constituents to surface waters.

\section{Sample Collection and Preparation}

A count of the various types of samples collected from each of the three basins studied is listed in Table 1. In the table, "site dupes" refers to sample quality control site duplicates collected in the field. A sample site map is provided in figure 2.

Table 1. Count of types of samples collected in this study.

\begin{tabular}{|l|l|l|l|l|}
\hline & Total & $\begin{array}{l}\text { Panther } \\
\text { Creek }\end{array}$ & $\begin{array}{l}\text { Middle Fork } \\
\text { Salmon }\end{array}$ & Main Salmon \\
\hline Water & & & & \\
\hline $\mathbf{1 9 9 6}$ & 80 & 11 & 48 & 21 \\
\hline Site dupes, 1996 & 4 & 1 & 2 & 1 \\
\hline $\mathbf{2 0 0 1}$ & 93 & 31 & 44 & 18 \\
\hline Site dupes, 2001 & 4 & 1 & 3 & 0 \\
\hline Stream Sediments & & & & \\
\hline $\mathbf{1 9 9 6}$ & 86 & 24 & 42 & 20 \\
\hline Site dupes, 1996 & 4 & 1 & 2 & 1 \\
\hline $\mathbf{2 0 0 1}$ & 92 & 32 & 42 & 18 \\
\hline Site dupes, 2001 & 5 & 1 & 4 & 0 \\
\hline Concentrates, 1996 & 34 & 6 & 10 & 18 \\
\hline
\end{tabular}

Discrepancies in the above table for 1996 and 2001 sample totals reflect the fact that not every site sampled in 1996 was resampled in 2001 and vice versa. Paired sites where samples were collected in both 1996 and 2001 include 24 sites on Panther Creek, 42 sites on the Middle Fork of the Salmon River, and 17 sites on the Salmon River.

\section{Stream Sediments}

Each stream-sediment sample consisted of alluvium from the active stream channel, composited by collecting sediment increments from several places at the sample site, generally along a 30-ft (10-m) stretch of the channel. In order to improve sample representativity, an attempt was made to collect 20 to 30 increments at each site. However, at some sites sparse distribution of available sediment reduced the number of increments to less than 10 . The sediment was sieved on site with a 10 mesh $(2 \mathrm{~mm})$ stainless steel screen. A 2-lb $(0.9-\mathrm{kg})$ sample of minus-10 mesh sediment was collected in a cloth bag and air-dried.

In the laboratory, stream sediment samples were air-dried and sieved at 80 mesh $(0.177$ $\mathrm{mm}$ ), following the method of Peacock and others (1996). The coarse fraction was discarded. The fine sediment fractions were pulverized to a fine flour consistency (minus-100 mesh/0.149 $\mathrm{mm}$ ), with clean quartz sand pulverized between each sample to reduce risk of crosscontamination. For each sample, an approximate 6.5-oz (185-g) portion was saved for chemical analyses; any remaining material was subsequently archived.

\section{Heavy Mineral Concentrates}

Panned concentrate samples were collected from the same active alluvium as sediment samples, from around boulders and in coarse gravels. The pan concentrate samples were not composited as the stream sediment samples were, but were collected as grab samples in areas where heavy minerals tend to accumulate. A 14-inch stainless steel gold pan was filled with 
stream sediment sieved to minus-10 mesh $(2 \mathrm{~mm})$ with a stainless steel screen, resulting in approximately $16 \mathrm{lb}(7.2 \mathrm{~kg})$ of material. This sieved alluvium was panned at the site when running water was available, or collected in a cloth bag for later panning. The alluvium was panned until most of the less-dense minerals (primarily quartz and feldspar), organic materials, and clays were removed. Generally, one to three percent of the original sample remained after panning. The panned sample was bagged, air-dried, and saved for further laboratory preparation.

In the laboratory, panned concentrate samples were sieved to minus-20 mesh $(0.84 \mathrm{~mm})$, and then gravity separated using bromoform (specific gravity about 2.85) to remove remaining light minerals, primarily quartz and feldspar. The resultant heavy-mineral-concentrate sample was separated into magnetic, weakly magnetic, and nonmagnetic fractions using a modified Frantz Isodynamic Separator (Taylor and Theodorakos, 1996). The magnetic fraction was extracted at a setting of 0.25 ampere and contains primarily magnetite and ilmenite. The weakly magnetic fraction was extracted at a setting of 1.75 ampere and consists largely of ferromagnesian silicates and iron oxides. The remaining nonmagnetic fraction may contain many ore-related minerals including sulfide minerals, gold and other native metals, and some accessory oxides and silicates. The nonmagnetic heavy-mineral-concentrate samples were split using a Jones splitter. One split was hand ground with an agate mortar and pestle for chemical analysis and the other split was used for microscopic mineralogical analysis. Clean quartz sand was hand ground between samples to clean the mortar and pestle, thereby reducing the risk of cross-contamination between samples.

\section{Water}

This study was reconnaissance in nature, covering a large area in a short period of time. Thus, for collection of water samples, we did not adhere strictly to the rigorous "parts per billion" protocol established by the U.S. Geological Survey Water Resources Division (Horowitz and others, 1994). Rather, procedures were streamlined to facilitate the sample collection process, as described below.

A clean 1-liter polypropylene bottle was used for water sampling. The bottle was rinsed prior to sample collection. While rigorous width- and depth-integrated sampling protocol was not followed, an attempt at collecting integrated samples was made by collecting at intervals across the entire width of the stream or river (width integration). We collected samples below riffles or white water - natural zones of mixing - as a proxy for depth integration. The filled 1liter bottles were capped and shaken prior to collecting sub-samples from them. Sub-samples were collected in polypropylene bottles rinsed on site with unfiltered water for unfiltered water samples and with filtered water for filtered samples. Bottles for acidified samples were prerinsed in the laboratory with a 10 percent nitric acid solution. In all cases, care was taken at each site to minimize contamination by rinsing bottles and equipment; and by using new, unpowdered vinyl gloves, disposable equipment (filters, syringes, etc.), and clean plastic sheets to cover onsite work areas.

At most sites, three sub-samples were collected: (1) an unacidified, filtered raw water sample (FU) for anion analysis, (2) an acidified, unfiltered sample (RA) for trace and major cation analysis of both dissolved and suspended species, (3) an acidified, filtered sample (FA) for trace and major cation analysis of dissolved species. The unacidified samples were kept in an iced cooler in the field and in a refrigerator in the laboratory prior to analysis. Samples were filtered with sterile 0.45 -micron disposable filters and acidified to $\mathrm{pH}<2$ with ultra-pure, concentrated nitric acid to prevent precipitation of metals and bacterial growth. 
At a few sites in the 1996 study (principally hot springs) water was collected for ferrous iron content. Sample collection bottles were protected from direct sunlight. The ferrous iron water samples were filtered as described above; collected in opaque, dark brown polypropylene bottles to prevent light penetration; and acidified with ultra-pure, concentrated hydrochloric acid to $\mathrm{pH}<2$. For the 2001 study, ferrous iron was determined on all samples using field-portable kits, described below under the Analytical Techniques section.

Mercury was not determined on water samples collected in the 1996 study. However, in 2001 water samples for $\mathrm{Hg}$ analysis were collected. At each water sample site, a filtered $(0.45$ micron disposable filter), preserved $\left(\mathrm{K}_{2} \mathrm{Cr}_{7} \mathrm{O}_{7}-\mathrm{HNO}_{3}\right)$ sample was collected in an acid-rinsed $\left(\mathrm{HNO}_{3}\right)$ glass bottle with Teflon lid.

Other water data collected and recorded on-site include temperature, $\mathrm{pH}$, conductivity, dissolved oxygen content, an estimate of the water flow rate, and total alkalinity. Conductivity and $\mathrm{pH}$ were collected with Orion meters calibrated with standards at each site prior to sample measurement. For pH, two calibration buffer standards that bracketed the sample's $\mathrm{pH}$ were used. Dissolved oxygen content was determined using a field-portable CHEMetrics, Inc. colorimetric test kit. Total alkalinity measurements were collected from using a field-portable CHEMetrics, Inc. titration kit. Alkalinity is a measure of total acid-neutralizing capacity of water and is reported in ppm as $\mathrm{CaCO}_{3}$. Alkalinities for all 1996 water samples were determined with the field kit. Alkalinities for 2001 water samples were determined with the field kit, but for those samples with alkalinity concentrations below $25 \mathrm{ppm}$ an additional unfiltered, unacidified sample was collected and refrigerated for laboratory analysis.

Flow rates were not calculated, but rather are ballpark estimates and should be used conservatively. These flow estimates were determined by the 3 river guides on the trip, whose combined river floating experience totaled over 90 years, with much of that experience on Idaho rivers. Later, the flow estimates for the Middle Fork, the Main Salmon, and Panther Creek were compared with published flow records for the 1996 sampling period (Brennan and others, 1996), with unpublished records maintained by the Middle Fork Ranger District, and with provisional flow data for the 2001 sampling period available from the U.S. Geological Survey Water Resources Discipline website (http://id.waterdata.usgs.gov/). The flow estimates for the 1996 study were found to be within $\pm 25 \%$ and for the 2001 study were found to be within $\pm 12 \%$ at locations where flows are officially recorded.

\section{ANALYTICAL TECHNIQUES}

A large number of chemical elements were determined, using a variety of quantitative and semi-quantitative analytical techniques. Table 2 shows the various elements determined and analytical methods used for each of the sample media collected in the study. A brief description and published references for each analytical method is given below. Descriptions and quality assurance/quality control (QA/QC) protocol for most of the analytical methods used in this study are found in Arbogast (1996) and Taggart (2002). U.S. Geological Survey laboratories analyzed all water and heavy-mineral concentrate samples. Stream sediment samples were analyzed by XRAL Laboratories, Inc. of Don Mills, Ontario, Canada, under a contract with the U.S. Geological Survey. 
Table 2. Elements determined and analytical methods used for all sample media. [method codes: MW, water by ICP mass spectrometry; EW, water by ICP atomic emission spectrometry; $\mathrm{IC}$, water by ion chromatography; $\mathrm{AF}$, atomic fluorescence spectrometry, $\mathrm{CO}$, colorimetry, $\mathrm{TI}$, titration, ET, solid by ICP atomic emission spectrometry; EP, solid by partial-extraction ICP atomic emission spectrometry; FA, fire assay atomic absorption; HY, solid by hydride generation atomic absorption spectrometry; CV, solid by cold-vapor atomic absorption spectrometry; CT, coulometric titration; LE, Leco analyzer; DI, for organic carbon, the calculated difference between LE and CT values; ES, solid by semi-quantitative emission spectrography]

\begin{tabular}{|c|c|c|}
\hline Sample Media & Method & Elements determined \\
\hline \multirow[t]{2}{*}{$\begin{array}{l}\text { Water, } \\
\text { filtered/acidified (FA) and } \\
\text { unfiltered/acidified (RA) }\end{array}$} & MW & $\begin{array}{l}\mathrm{Ag}, \mathrm{Al}, \mathrm{As}, \mathrm{Au}, \mathrm{Ba}, \mathrm{Be}, \mathrm{Bi}, \mathrm{Ca}, \mathrm{Cd}, \mathrm{Ce}, \mathrm{Co}, \mathrm{Cr}, \mathrm{Cs}, \mathrm{Cu}, \mathrm{Dy}, \\
\mathrm{Er}, \mathrm{Eu}, \mathrm{Fe}, \mathrm{Ga}, \mathrm{Gd}, \mathrm{Ge}, \mathrm{Hf}, \mathrm{Ho}, \mathrm{In}, \mathrm{K}, \mathrm{La}, \mathrm{Li}, \mathrm{Mg}, \mathrm{Mn}, \mathrm{Mo}, \mathrm{Na} \text {, } \\
\mathrm{Nb}, \mathrm{Nd}, \mathrm{Ni}, \mathrm{P}, \mathrm{Pb}, \mathrm{Pr}, \mathrm{Rb}, \mathrm{Re}, \mathrm{Sb}, \mathrm{Se}, \mathrm{Si}, \mathrm{Sm}, \mathrm{Sn}, \mathrm{SO}_{4}^{2}, \mathrm{Sr} \\
\mathrm{Ta}, \mathrm{Tb}, \mathrm{Te}, \mathrm{Th}, \mathrm{Tl}, \mathrm{Tm}, \mathrm{U}, \mathrm{V}, \mathrm{W}, \mathrm{Y}, \mathrm{Yb}, \mathrm{Zn}, \mathrm{Zr}\end{array}$ \\
\hline & EW & $\begin{array}{l}\mathrm{Ag}, \mathrm{Al}, \mathrm{As}, \mathrm{B}, \mathrm{Ba}, \mathrm{Be}, \mathrm{Ca}, \mathrm{Cd}, \mathrm{Co}, \mathrm{Cr}, \mathrm{Cu}, \mathrm{Fe}, \mathrm{K}, \mathrm{Li}, \mathrm{Mg}, \mathrm{Mn}, \\
\mathrm{Mo}, \mathrm{Na}, \mathrm{Ni}, \mathrm{P}, \mathrm{Pb}, \mathrm{Sb}, \mathrm{Si}, \mathrm{Sr}, \mathrm{Ti}, \mathrm{V}, \mathrm{Zn}\end{array}$ \\
\hline $\begin{array}{l}\text { Water, } \\
\text { Filtered/not acidified (FU) }\end{array}$ & IC & $\mathrm{Cl}^{\prime}, \mathrm{F}, \mathrm{NO}_{3}, \mathrm{SO}_{4}^{2-2}$ \\
\hline $\begin{array}{l}\text { Water, } \\
\text { Filtered/preserved (HG) }\end{array}$ & $\mathrm{AF}$ & $\mathrm{Hg}$ \\
\hline $\begin{array}{l}\text { Water, } \\
\text { Filtered/acidified (FE) }\end{array}$ & $\mathrm{CO}$ & $\mathrm{Fe}^{2+}$ \\
\hline $\begin{array}{l}\text { Water, } \\
\text { unfiltered/not acidified (ALK) }\end{array}$ & TI & Alkalinity \\
\hline \multirow[t]{9}{*}{ Stream Sediments } & ET & $\begin{array}{l}\mathrm{Ag}, \mathrm{Al}, \mathrm{As}, \mathrm{Au}, \mathrm{Ba}, \mathrm{Be}, \mathrm{Bi}, \mathrm{Ca}, \mathrm{Cd}, \mathrm{Ce}, \mathrm{Co}, \mathrm{Cr}, \mathrm{Cu}, \mathrm{Eu}, \mathrm{Fe}, \\
\mathrm{Ga}, \mathrm{Ho}, \mathrm{K}, \mathrm{La}, \mathrm{Li}, \mathrm{Mg}, \mathrm{Mn}, \mathrm{Mo}, \mathrm{Na}, \mathrm{Nb}, \mathrm{Nd}, \mathrm{Ni}, \mathrm{P}, \mathrm{Pb}, \mathrm{Sc}, \mathrm{Sn} \text {, } \\
\mathrm{Sr}, \mathrm{Ta}, \mathrm{Th}, \mathrm{Ti}, \mathrm{U}, \mathrm{V}, \mathrm{Y}, \mathrm{Yb}, \mathrm{Zn}\end{array}$ \\
\hline & EP & $\mathrm{Ag}, \mathrm{As}, \mathrm{Au}, \mathrm{Bi}, \mathrm{Cd}, \mathrm{Cu}, \mathrm{Mo}, \mathrm{Pb}, \mathrm{Sb}, \mathrm{Zn}$ \\
\hline & FA & $\mathrm{Au}$ \\
\hline & HY & As, Sb, Se, Te, TI \\
\hline & CV & $\mathrm{Hg}$ \\
\hline & CT & $\mathrm{CO}_{2}$ \\
\hline & $\mathrm{TI}$ & $\mathrm{FeO}$ \\
\hline & LE & total carbon, total sulfur \\
\hline & $\mathrm{DI}$ & organic carbon \\
\hline Heavy Mineral Concentrates & ES & $\begin{array}{l}\mathrm{Ag}, \mathrm{As}, \mathrm{Au}, \mathrm{B}, \mathrm{Ba}, \mathrm{Be}, \mathrm{Bi}, \mathrm{Ca}, \mathrm{Cd}, \mathrm{Co}, \mathrm{Cr}, \mathrm{Cu}, \mathrm{Fe}, \mathrm{Ga}, \mathrm{Ge}, \\
\mathrm{La}, \mathrm{Mg}, \mathrm{Mn}, \mathrm{Mo}, \mathrm{Na}, \mathrm{Nb}, \mathrm{Ni}, \mathrm{P}, \mathrm{Pb}, \mathrm{Pd}, \mathrm{Pt}, \mathrm{Sb}, \mathrm{Sc}, \mathrm{Sn}, \mathrm{Sr}, \mathrm{Th} \\
\mathrm{Ti}, \mathrm{V}, \mathrm{W}, \mathrm{Y}, \mathrm{Zn}, \mathrm{Zr}\end{array}$ \\
\hline
\end{tabular}

In this study, quality assurance/quality control (QA/QC) concerns were addressed through the use of internal reference standards, field blanks, sample site duplicates, and analytical duplicates. QA/QC samples comprised approximately 10 percent of the total number of samples analyzed. Reference standards were interspersed with batches of samples and the analyses of the reference standards were checked to assure that reported values were within \pm 20 percent of the accepted values. Analytical duplicates were interspersed with batches of samples and the analyses of the duplicates were checked to assure that the relative standard deviation (RSD) between duplicates was no greater than 20 percent. Water samples included field blanks of de-ionized water, used to check for contamination from sampling equipment and preservatives. Field blanks were collected near the beginning, midway, and near the end of the sampling period, following the same procedures as those used for normal water samples. Sediment and water sample site duplicates were collected randomly. The site duplicates were 
collected following the same procedures as those used for normal water and sediment samples. Only the sample site duplicate analyses are retained in the published data files.

In the data files for the various sample media, discrepancies in element concentration for the same sample determined by different analytical methods (for example, gold) may be attributable to the particulate nature of certain elements, different sample weights used, different dissolution and extraction procedures, and to instrumental bias. For gold in particular, the fire assay atomic absorption spectrometric (FA) analytical method provides the most statistically representative results, due to the larger sample weight analyzed and lower determination limits.

For simplicity, reporting units for all sample media are percent $(\%)$, parts per million $(\mathrm{ppm})$, or parts per billion ( $\mathrm{ppb})$. Water sample analyses, which are commonly reported in the literature as milligrams per liter or micrograms per liter, are given here as ppm or ppb, respectively.

\section{Techniques Used on Stream Sediment and Concentrate Samples Inductively Coupled Plasma-Atomic Emission Spectrometry-Stream Sediments}

Two ICP-AES methods were used in the study for multi-element analyses of stream sediments. The first method, a 40-element total digestion method (designated "ET" in Table 2 and in the data files), was used on all 1996 and 2001 stream sediment samples. The second method, a 10-element, partial-extraction method (designated "EP" in Table 2 and in the data files), was used only on the 1996 samples.

In the first multi-element method (ET), 40-element ICP-AES, samples were digested and analyzed following the procedure of Briggs (1996). Samples (0.2 g) were digested using a mixture of hydrochloric, nitric, perchloric, and hydrofluoric acids, and the solutions were heated at $110^{\circ} \mathrm{C}$ until dry. Additional perchloric acid and water were added to the residue and the mixture was then taken to dryness at $150^{\circ} \mathrm{C}$. Aqua regia and dilute nitric acid were added to the residue to bring the solution to a final volume, the solution was heated at $95^{\circ} \mathrm{C}$ for an hour, and then, after cooling, the sample was aspirated into the argon plasma and element concentrations were determined simultaneously with a multi-channel ICP-AES instrument. Calibration is performed by standardizing with digested rock reference materials and with a series of multielement solution standards. Limits of determination for 40-element ICP-AES are shown in Appendix Table A1. Analytical Performance: Data were deemed acceptable if recovery for all 40 elements was $\pm 15 \%$ at five times the Lower Limit of Determination (LOD) and the calculated Relative Standard Deviation (RSD) of duplicate samples was no greater than $15 \%$.

In the second multi-element method (EP), concentrations of $\mathrm{Ag}, \mathrm{As}, \mathrm{Au}, \mathrm{Bi}, \mathrm{Cd}, \mathrm{Cu}, \mathrm{Mo}$, $\mathrm{Pb}, \mathrm{Sb}$, and $\mathrm{Zn}$ were determined on samples by a 10-element ICP-AES partial extraction procedure developed by Motooka (1996). This procedure solubilizes metals not tightly bound in the silicate lattice of rocks, soils, and stream sediments; metals tightly bound in highly resistant minerals are not extracted. Samples $(1 \mathrm{~g})$ were decomposed with concentrated hydrochloric acid and hydrogen peroxide in a hot-water bath. Metals were extracted in diisobutyl ketone (DIBK)/Aliquat 336 in the presence of ascorbic acid and potassium iodide. The DIBK/Aliquat 336 phase was then aspirated directly into the argon plasma and element concentrations were determined simultaneously with a multi-channel ICP-AES instrument. Limits of determination for 10-element ICP-AES are shown in Appendix Table A2. It is important to note that this procedure is a partial digestion and depending on element availability, results may be biased low when compared to other methods of analyses. In addition, high $\mathrm{Cu}$ content in samples can cause interferences for elements determined by this method; for samples with high $\mathrm{Cu}$ content, data by 
this method should be used cautiously (J. M. Motooka, U.S. Geological Survey, oral commun., 1995). For the above and other reasons, this method was not used for samples collected in the 2001 study. Analytical Performance: Data were deemed acceptable if recovery for all 10 elements was $\pm 20 \%$ at five times the LOD and the calculated RSD of duplicate samples was no greater than $20 \%$.

\section{Atomic Absorption Spectrometry-Stream Sediments}

Several atomic absorption spectrometric (AAS) methods were used for determining antimony, arsenic, gold, mercury, selenium, tellurium, and thallium in stream sediment samples. Determination limits for these techniques are given in Appendix Table A2.

Arsenic and antimony in stream sediment samples were determined atomic absorption spectrometry by XRAL, Inc., using a method that demonstrates an analytical performance identical to or exceeding the performance described in Hageman and Welsch (1996) and Hageman and others (2002). A $0.1 \mathrm{~g}$ sample was weighed out into a zirconium crucible and approximately $0.75 \mathrm{~g}$ of sodium peroxide was added. The mixture was heated in a muffle furnace at $750^{\circ} \mathrm{C}$ for four minutes, the cooled. Fifteen $\mathrm{ml}$ of water and $5 \mathrm{ml}$ of concentrated $\mathrm{HCl}$ was added and the mixture was shaken. Then $0.25 \mathrm{ml}$ of an ascorbic acid-potassium iodide solution was added. The solution was diluted with $20 \% \mathrm{HCl}$ and stood overnight. Arsenic and antimony were then measured using hydride generation atomic absorption spectrometry. The optimum concentration ranges without sample dilution for these elements in various solid phase sample media are: As- $0.6 \mathrm{ppm}$ to $20 \mathrm{ppm}$ and Sb-0.6 ppm to $20 \mathrm{ppm}$. This method is designated $\mathrm{HY}$ in Table 2 and in the data files. Analytical Performance: Data were deemed acceptable if recovery of As and $\mathrm{Sb}$ was $\pm 20 \%$ at five times the LOD and the calculated percent RSD of duplicate samples was no greater than $20 \%$.

Gold in stream sediments was determined by graphite furnace atomic absorption spectrometry for samples collected prior to 1997, and by fire assay atomic absorption spectrometry for samples collected in 1997 and later. In the graphite furnace method, samples were digested using a hydrobromic acid-bromine digestion, an MIBK extraction, and then gold was determined on the solutions by atomic absorption (O'Leary and Meier, 1996). In the fire assay method (XRAL Laboratories, Inc.), a mixture of finely pulverized sample with about three parts of a flux are fused until the product is molten. A lead compound in the flux is reduced by other flux constituents to metallic lead. The metallic lead collects all gold, together with silver, platinum metals, and small quantities of certain base metals present in the sample and falls to the bottom of the crucible to form a lead button. The choice of a suitable flux depends on the character of the ore. The lead button is cupelled to oxidize the lead leaving behind a dore bead containing the precious metals. The dore bead is then transferred to a test tube, dissolved with aqua regia, diluted to a specific volume and determined by atomic absorption spectrometry. The graphite furnace Au and fire assay Au methods are collectively designated FA in Table 2 and in the data files. Analytical Performance: Data were deemed acceptable if recovery of gold was $\pm 20 \%$ at five times the LOD and the calculated percent RSD of duplicate samples was no greater than $20 \%$.

Mercury in stream sediment samples was determined cold vapor atomic absorption by XRAL, Inc., using a method that demonstrates an analytical performance identical to or exceeding the performance described in O'Leary and others (1996). Mercury was determined by weighing out $0.1 \mathrm{~g}$ of sample and digesting it with a mixture of nitric and hydrochloric acids. Potassium permanganate, sulfuric acid and potassium persulphate were added to the solution, followed by a NaCl-hydroxylamine solution. The solution was diluted to $25 \mathrm{~mL}$, mixed 
thoroughly, allowed to settle, and then transferred to the auto sampler rack of the Perkin-Elmer Flow Injection Mercury System (FIMS-100), a cold-vapor atomic absorption mercury analyzer. Mercury concentration in the solution was determined after liberating the mercury as vapor using stannous chloride reducing agent. This method is designated CV in Table 2 and in the data files. Analytical Performance: Data were deemed acceptable if recovery of mercury was $\pm 20 \%$ at five times the LOD and the calculated percent RSD of duplicate samples was no greater than $20 \%$.

Selenium in stream sediment samples was determined by continuous-flow hydride generation AAS by XRAL, Inc., using a method that demonstrates an analytical performance identical to or exceeding the performance described in Hageman and Welsch (1996) and Hageman and others (2002). The samples $(0.25 \mathrm{~g})$ were digested by adding concentrated nitric, perchloric, and hydrofluoric acids and heating. After cooling, hydrochloric and nitric acids were added and the solutions again heated and cooled. The samples were diluted and selenium concentration was determined using a hydride generation atomic absorption spectrometer. This method is designated HY in Table 2 and in the data files. Analytical Performance: Data for selenium were deemed acceptable if recovery of that element was $\pm 20 \%$ at five times the LOD and the calculated percent RSD of duplicate samples was no greater than $20 \%$.

Tellurium was determined by weighing $0.25 \mathrm{~g}$ of sample into a Teflon tube, adding a mixture of nitric, hydrofluoric, and perchloric acids and heating. After the solution cooled, hydrochloric and nitric acids were added, the solution was heated again, and cooled. The samples were diluted and analyzed using hydride-generation atomic absorption spectrometry, by XRAL Laboratories, Inc., using a method that demonstrates an analytical performance identical to or exceeding the performance described in O'Leary (1996). This method is designated HY in Table 2 and in the data files. Analytical Performance: Data for tellurium were deemed acceptable if recovery of that element was $\pm 20 \%$ at five times the LOD and the calculated percent RSD of duplicate samples was no greater than $20 \%$.

Thallium was determined by weighing $0.1 \mathrm{~g}$ of sample into a zirconium crucible, adding $0.75 \mathrm{~g}$ of sodium peroxide, and mixing. The mixture was heated in a muffle furnace set at $750^{\circ} \mathrm{C}$ for four minutes and then cooled. Then $15 \mathrm{ml}$ of water and $5 \mathrm{ml}$ of concentrated $\mathrm{HCl}$ was added. The mixture was shaken and $0.25 \mathrm{ml}$ of an ascorbic acid-potassium iodide solution was added. The solution was then diluted with $20 \% \mathrm{HCl}$ and stood overnight. Thallium concentration was determined using hydride generation atomic absorption spectrometry by XRAL Laboratories, Inc., using a method that demonstrates an analytical performance identical to or exceeding the performance described in O'Leary (1996). This method is designated HY in Table 2 and in the data files. Analytical Performance: Data for thallium was deemed acceptable if recovery of that element was $\pm 20 \%$ at five times the LOD and the calculated percent RSD of duplicate samples was no greater than $20 \%$.

\section{LECO Analyzer-Stream Sediments}

A LECO analyzer was used to determine total carbon and total sulfur in stream sediments. Total carbon in geologic materials was determined by XRAL Laboratories, Inc., using an automated analyzer. The method is similar to that of Brown and Curry (2002a). A 0.25 g sample was combusted in an oxygen atmosphere at $1370^{\circ} \mathrm{C}$ to oxidize carbon to carbon dioxide. Moisture and dust were removed and the carbon dioxide gas was measured by a solid state infrared detector. The operating range for total carbon is from $0.05 \%$ to about $30 \%$. This method is designated LE in Table 2 and in the data files. Analytical Performance: Data were deemed acceptable if recovery of total carbon was $\pm 15 \%$ at five times the LOD and the calculated percent RSD of duplicate samples was no greater the $15 \%$. 
Total sulfur was determined by XRAL Laboratories, Inc., using an automated analyzer. The method is similar to that of Brown and Curry (2002b). A $0.25 \mathrm{~g}$ sample was mixed with iron chips and LECOCEL and was heated in a combustion tube in a stream of oxygen at high temperature. Sulfur was oxidized to sulfur dioxide. Moisture and dust were removed and the sulfur dioxide gas was then measured by an infrared detector. The reporting range for total sulfur is from $0.05 \%$ to about $35 \%$. This method is designated LE in Table 2 and in the data files. Analytical Performance: Data were deemed acceptable if recovery of total sulfur was $\pm 15 \%$ at five times the LOD and the calculated percent RSD of duplicate samples was no greater than $15 \%$.

\section{Titration-Stream Sediments}

Stream sediment samples collected in 2001 were analyzed for ferrous iron $(\mathrm{FeO})$ using a titration method by XRAL Laboratories, Inc., using a method that demonstrates an analytical performance identical to or exceeding the performance described in Papp and others (1996a). A 0.5 gram sample was digested using a mixture of sulfuric, hydrofluoric, and hydrochloric acids. The solution was titrated with potassium dichromate using sodium diphenylanime sulphonate as an indicator. The lower reporting limit is $0.01 \% \mathrm{FeO}$. This method is designated TI in Table 2 and in the data files. Analytical Performance: The data were be deemed acceptable if recovery of $\mathrm{FeO}$ was $\pm 15 \%$ at five times the LOD and the calculated percent RSD of duplicate samples was no greater than $15 \%$. Organic carbon was determined arithmetically as the difference between total carbon and carbonate carbon.

\section{Coulometric Titration-Stream Sediments}

Carbonate carbon was determined as carbon dioxide by coulometric titration (Papp and others, 1996b), by XRAL Laboratories, Inc. The sample was treated with hot $2 \mathrm{~N}$ perchloric acid and the evolved carbon dioxide was passed into a cell containing a solution of monoethanolamine. The carbon dioxide, quantitatively absorbed by the monoethanolamine, was coulometrically titrated using platinum and silver/potassium-iodide electrodes. The lower reporting limit is $0.01 \%$ carbon dioxide and samples containing up to $50 \%$ carbon dioxide may be analyzed. Sample size was adjusted from $0.5 \mathrm{~g}$ for the range 0.01 to $5 \%$ carbon dioxide, $0.1 \mathrm{~g}$ for the range 5 to $10 \%$ carbon dioxide, and $0.02 \mathrm{~g}$ for greater than $10 \%$ carbon dioxide. This method is designated CT in Table 2 and in the data files. Analytical Performance: Data were be deemed acceptable if recovery for carbonate carbon was $\pm 15 \%$ at five times the lower limit of determination and the calculated percent RSD of duplicate samples was no greater than $15 \%$.

Organic carbon was determined arithmetically as the difference between total carbon and carbonate carbon.

\section{Semiquantitative Emission Spectrography_Concentrates}

The minus-20-mesh nonmagnetic heavy-mineral-concentrate samples were analyzed for 37 major, minor, and trace elements by a direct-current arc, semiquantitative emission spectrographic (SES) technique (Adrian and others, 1996). Spectrographic results were determined by visually comparing spectra derived from the sample and recorded on photographic film against spectra obtained from laboratory reference standards. Standard concentrations are geometrically spaced over any given order of magnitude as follows: 100, 50, 20, 10, 5, 2 etc. Samples whose concentrations were estimated to fall between those values were assigned values of 70, 30, 15, 7, 3, 1.5 etc. Elements determined by SES are Ag, As, $\mathrm{Au}, \mathrm{B}, \mathrm{Ba}, \mathrm{Be}, \mathrm{Bi}, \mathrm{Ca}, \mathrm{Cd}$, $\mathrm{Co}, \mathrm{Cr}, \mathrm{Cu}, \mathrm{Fe}, \mathrm{Ga}, \mathrm{Ge}, \mathrm{La}, \mathrm{Mg}, \mathrm{Mn}, \mathrm{Mo}, \mathrm{Na}, \mathrm{Nb}, \mathrm{Ni}, \mathrm{P}, \mathrm{Pb}, \mathrm{Pd}, \mathrm{Pt}$, Sb, Sc, Sn, Sr, Th, Ti, V, W, $\mathrm{Y}, \mathrm{Zn}$, and Zr. This method is designated ES in Table 2 and in the data files. Limits of determination for elements determined by SES are listed in Appendix Table A3. Analytical 
Performance: The precision of this analytical technique is approximately \pm one reporting interval at the 83 percent confidence level and \pm two reporting intervals at the 96 percent confidence level (Motooka and Grimes, 1976).

\section{Techniques Used on Water Samples}

Inductively Coupled Plasma-Atomic Emission Spectrometry

Acidified water samples were analyzed for major (Al, Ca, Fe, K, Mg, $\mathrm{Na}$, and $\mathrm{Si}$ ) and selected trace elements following the ICP-AES method of Briggs and Fey (1996), revised in Briggs (2002) (designated EW in Table 2 and in the data files). Water samples were aspirated directly into an argon plasma and element concentrations were determined by ICP-AES. Limits of determination for the multi-element ICP-AES method for water samples are shown in Appendix Table A4. Analytical Performance: Data were deemed acceptable if recovery was $\pm 10 \%$ at five times the LOD and the calculated percent RSD of duplicate samples was no greater than $10 \%$.

\section{Ion Chromatography}

The anions $\mathrm{Cl}^{-}, \mathrm{F}^{-}, \mathrm{NO}_{3}{ }^{-}$, and $\mathrm{SO}_{4}{ }^{2-}$ were determined sequentially by ion chromatography on unfiltered, unacidified water samples following the methods of d'Angelo and Ficklin (1996) and Theodorakos (2002a). The raw water samples were kept cool from the time of collection until they were analyzed. The samples were injected into an ion chromatograph where ions of interest separate along an ion exchange separator column at different rates, depending on the affinity of each species for the ion-exchange resin. Samples then passed into a flow-through conductivity cell where the anions were detected and their peak heights were recorded. Unknown samples were compared with peak heights of calibration standards to determine sample concentrations. This method is designated IC in Table 2 and in the data files. Limits of determination for anions in raw water samples are shown in Appendix Table A5. Analytical Performance: Data were deemed acceptable if recovery was $\pm 10 \%$ at five times the LOD and the calculated percent RSD of duplicate samples was no greater than $10 \%$.

\section{Inductively Coupled Plasma-Mass Spectrometry}

Acidified-filtered and acidified-unfiltered waters were analyzed to determine over 50 elements by ICP-MS using a method developed by the U.S. Geological Survey (Meier and others, 1994; method revised in Lamothe and others, 2002). This method is designated MW in Table 2 and in the data files. The method is used to determine numerous elements directly in the water sample without the need for preconcentration or dilution. Element detection limits are in the sub-part-per-billion range and the working linear range is six orders of magnitude or more. By using derived response curves, percent of ionization, and natural isotopic abundances, estimates of concentrations for the elements can be determined in samples without the need of a calibration standard for every element. The method is most useful for trace elements in the parts-per-billion range; analyses for major elements in the parts-per-million range are less accurate and ICP-AES data should be used. Limits of determination for ICP-MS are shown in Appendix Table A6. Analytical Performance: Data were deemed acceptable if recovery was $\pm 10 \%$ at five times the LOD and the calculated percent RSD of duplicate samples was no greater than $10 \%$.

\section{Ferrous Iron by Colorimetry}

Through 1999, ferrous iron was determined in the laboratory by colorimetry, using a microprocessor-controlled, single beam Hach spectrophotometer (Hach Company, 1996; Theodorakos, 2002b). This method is designated CO in Table 2 and in the data files. Samples 
were introduced into an AccuVac Ampul and mixed quickly. Phenanthroline in the ampul reacts with ferrous iron in the sample to form an orange color in proportion to the ferrous iron concentration. Ferric iron does not react. The ampul was then placed into the spectrophotometer and concentration was measured. For concentrations higher than $3 \mathrm{ppm}$, solutions were diluted and re-analyzed. The lower limit of determination for this method is $0.01 \mathrm{ppm}$. Analytical Performance: Data were deemed acceptable if recovery was $\pm 10 \%$ at five times the LOD and the calculated percent RSD of duplicate samples was no greater than $10 \%$.

Starting in 2000, ferrous iron was determined in the field by visual colorimetry, using a portable CHEMets ${ }^{\circledR}$ test method (kit K-6210, CHEMetrics, Inc.; American Society for Testing and Materials, 2001a). Similar to the above laboratory method, in the ferrous iron CHEMets $\AA$ test method, ferrous iron reacts with 1,10-phenanthroline to form an orange colored complex in proportion to the ferrous iron concentration. The sample was collected in a glass ampul containing the reagent and mixed for 1 minute. Then the ampul was placed into a comparator containing standards of known ferrous iron concentration and the concentration was visually estimated. The lower limit of determination for this method is $0.1 \mathrm{ppm}$.

Mercury by Flow Injection-Cold Vapor-Atomic Fluorescence Spectrometry

Mercury was determined on 2001 samples only. This method is designated AF in Table 2 and in the data files. In the laboratory, preserved samples were mixed with stannous chloride. Mercury (II) was reduced to $\mathrm{Hg}^{\circ}$ in a flow injection manifold. The mercury vapor was purged from the aqueous phase with argon, passed through a drying tube, separated, and measured using flow injection cold vapor-atomic fluorescence spectrometry. For water samples, the lower limit of determination for this method is 5 parts per trillion. Operational details on this method are found in Hageman (2002). Analytical Performance: Data were deemed acceptable if recovery was $\pm 10 \%$ at five times the LOD and the calculated percent RSD of duplicate samples was no greater than $10 \%$.

\section{Alkalinity by Titration}

On-site alkalinity tests were done on all samples collected throughout the study, using field-portable CHEMets ®. titration kits (kits K-9810, K-9815, and K-9820, CHEMetrics, Inc.), following the method of the American Society for Testing and Materials (2001b). For 2001 water sites having low alkalinities $\left(<25 \mathrm{ppm}\right.$ as $\left.\mathrm{CaCO}_{3}\right)$, samples were also collected for laboratory alkalinity determination. The laboratory method is designated TI in Table 2 and in the data files. In the laboratory, an Orion 960 Autochemistry System was used for endpoint titration analysis. The titrant was added to $50 \mathrm{ml}$ of sample until a $\mathrm{pH}$ of 4.5 was achieved. Alkalinity was then calculated and reported in units of ppm as $\mathrm{CaCO}_{3}$. The lower limit of determination for this method is $1 \mathrm{ppm}$. Operational details on this method are found in Theodorakos (2002c). Analytical Performance: Data were deemed acceptable if recovery was $\pm 10 \%$ at five times the LOD and the calculated percent RSD of duplicate samples was no greater than $10 \%$.

\section{Which Technique Should I Use?}

In some instances, the same elements were determined by more than one analytical technique (Table 2). This section is provided as guidance for those cases where multiple values are listed for a given element in a sample. Filtered/acidified and unfiltered acidified water samples were analyzed by both ICP-MS and ICP-AES. In general, the ICP-AES method is more quantitative and data from this method is preferred over ICP-MS in those instances where values 
are given by both methods. This is particularly true for the major elements $\mathrm{Al}, \mathrm{Ca}, \mathrm{Fe}, \mathrm{K}, \mathrm{Mg}$, $\mathrm{Na}$, and $\mathrm{Si}$, where concentrations commonly exceeded the dynamic range of the ICP-MS instrument. For solid sample media, gold analyses by fire assay/graphite furnace atomic absorption are in all cases preferred over gold values reported by ICP-AES methods. As described above, high copper content in stream sediment samples can cause interferences on other elements in the 10-element, partial extraction ICP-AES method (EP). In these instances, the total extraction ICP-AES method (ET) is preferred for these elements. Analyses of stream sediments for As and Sb by hydride-generation atomic absorption spectrometry (HY) are preferred over the 10-element ICP-AES method (EP).

\section{DESCRIPTION OF DATA FILES}

The analytical data files are provided in two formats, as a Microsoft Access 2000 database and as separate Microsoft Excel .XLS files (version 3.0). The data in the Access database are arranged as a series of tables. The tables and their brief descriptions follow below. For those not using Microsoft Access 2000, the tables are saved as separate .XLS files with the same name and fields. The following abbreviations are used in the tables: FeOx, iron oxide; MnOx, manganese oxide; ppt, precipitate.

\section{FIELD NUMBERS}

The field number coding scheme is as follows: The first two numbers indicate the year the sample was collected. The next two letters (SA) indicate samples from Salmon National Forest. The next 3 digits indicate the sample site number. Collectively, these three parameters comprise the Site ID. Following the 3-digit number are suffixes indicating sample media type and, if applicable, QA/QC samples. The Site ID and media suffix together comprise the sample field number.

\section{Media}

Stream sediment

Suffix

Heavy-mineral concentrate

$\mathrm{S}$

Filtered/unacidified water, for anion analysis

$\mathrm{C}$

Unfiltered/acidified water, for cation analysis

FU

Filtered/acidified water, for cation analysis

RA

FA

Water for ferrous iron analysis, for ferrous iron analysis $\quad$ FE

Unfiltered/unacidified water, for alkalinity analysis

Filtered/acidified water, for mercury analysis

ALK

HG

For QA/QC samples, a “D” suffix immediately following the 3-digit number indicates a sample site duplicate. These suffixes precede the sample media type suffix. Thus, field number 96SA072S indicates a sediment sample from site 96SA072, while field number 96SA072DS indicates a site duplicate of the same.

\section{COORDINATES}

Sample site locations are given in the SampleSiteInfo table as both degrees-minutesdecimal seconds and decimal degrees. Initially in the 1996 study (Eppinger and others, 2001), coordinates were determined by digitizing sample locations as plotted on U.S. Geological Survey 1:24,000-scale topographic maps. However, in the 2001 study, the sites were re-occupied and 
sample site coordinates were determined with a Global Positioning System (GPS) unit. The 2001 GPS coordinates are preferred and provided here. The datum and spheroid used are WGS84.

\section{GEOCHEMICAL ANALYSES}

All geochemical data are given in the following format. Field identifiers consist of a single line. The first one or two letters give the chemical element symbol, then units of measurement, and finally a code for the analytical method used for the element in that particular column. These three items are separated by underscores. Element symbols and associated names are shown in the appendix. Units of measurement are: PPM, parts per million; PPB, parts per billion; and PCT, percent. The analytical methods and associated code letters are:

$\mathrm{AF} \quad$ atomic fluorescence spectrometry for mercury (water samples)

$\mathrm{CO}$ colorimetric method for ferrous iron (water samples)

CT coulometric titration for carbonate (solid samples)

CV cold-vapor atomic absorption spectrometry for mercury (solid samples)

DI for organic carbon, calculated difference between LE and CT values (solid samples)

EP inductively coupled plasma-atomic emission spectrometry (partial extraction, solids)

ET inductively coupled plasma-atomic emission spectrometry (total digestion, solid samples)

ES semiquantitative emission spectrography (solid samples)

EW inductively coupled plasma-atomic emission spectrometry (water samples)

FA fire assay atomic absorption spectrometry (solid samples)

HY hydride generation atomic absorption spectrometry (solid samples)

IC ion chromatography (water samples)

LE LECO analyzer for total carbon and total sulfur (solid samples)

MW inductively coupled plasma-mass spectrometry (water samples)

TI titration for alkalinity (water samples)

For example, As_PPM_ET indicates arsenic, in parts per million, determined by total digestion inductively coupled plasma-atomic emission spectrometry. For all geochemical data except heavy mineral concentrates, a negative sign "-_" in front of the value indicates that an element was not observed at the lower limit of determination shown. A blank entry indicates that the sample was not analyzed for that particular element. For heavy mineral concentrate geochemical analyses, the following symbols are used: $\mathrm{N}(\mathrm{x})$, not detected at the limit of determination given in parentheses; L (x), detected, but less than the limit of determination given in parentheses; $G$ $(\mathrm{x})$, greater than the upper determination limit given in parentheses. Thus, for the heavy mineral concentrates, values are given as text fields rather than numeric fields in the database tables.

\section{DESCRIPTIONS OF TABLES AND FIELDS WITHIN TABLES}

Below are brief descriptions of the various tables and fields contained within the tables. First are tables containing sample and site descriptive information, next are tables containing chemical analyses. Following those is a table with fields specific to the wildfire study. Fields common to all or most tables are listed together. Fields unique to specific tables are listed below those tables.

Tables containing sample and site descriptive information

\section{Table Description}

SAMPLOG table of all sample sites and the sample media collected at each site 


\begin{tabular}{|c|c|c|}
\hline Fields: & Field Type: & Contents: \\
\hline Site_ID & text & sample site identifier (field is common to all tables) \\
\hline QA/QC_Sample & text & QA/QC sample site duplicate \\
\hline Water_FU & number & filtered ( 0.45 micron), unacidified water \\
\hline Water_RA & number & unfiltered, acidified $\left(\mathrm{HNO}_{3}\right)$ water \\
\hline Water_FA & number & filtered (0.45 micron), acidified $\left(\mathrm{HNO}_{3}\right)$ water \\
\hline Water_FE2+ & number & $\begin{array}{l}\text { filtered }(0.45 \text { micron }) \text {, acidified }(\mathrm{HCl}) \text { water for } \\
\mathrm{Fe}^{2+} \text { analysis performed in the laboratory }\end{array}$ \\
\hline Water_HG & number & $\begin{array}{l}\text { filtered }(0.45 \text { micron }) \text {, preserved }\left(\mathrm{K}_{2} \mathrm{Cr}_{7} \mathrm{O}_{7}-\mathrm{HNO}_{3}\right) \\
\text { water for } \mathrm{Hg} \text { analysis }\end{array}$ \\
\hline Water_ALK & number & $\begin{array}{l}\text { unfiltered, unacidified water for alkalinity } \\
\text { performed in the laboratory }\end{array}$ \\
\hline Stream_Sed & number & stream sediment sample (minus 80 mesh) \\
\hline Concentrate & number & heavy-mineral concentrate sample (minus 20 mesh) \\
\hline Notes & text & any additional notes regarding samples collected \\
\hline
\end{tabular}

Table

SITEINFO

Fields:

Site_ID

LatDeg

LatMin

LatSec

LongDeg

LongMin

LongSec

LatitudeDD

LongitudeDD

XY_Error_ft

Datum

Spheroid

Elev_ft

7_1/2_Quad

County

Date_Coll

Time_Coll

Location_Info

Site_Descript

Deposit_Type

Deposit_Name

Mine_District

Weather

Air_Temp_C

\section{Description}

information relevant to all sample sites

\section{Field Type: Contents:}

text

number

number

number

number

number

number

number

number

number

text

text

number

text

text

date/time

date/time

text

text

text

text

text

text

text

latitude, degrees

latitude, minutes

GPS unit, in feet

topographic map sample site identifier (field is common to all tables)

latitude, decimal seconds

longitude, degrees

longitude, minutes

longitude, decimal seconds

latitude in decimal degrees

longitude in decimal degrees

location error in $\mathrm{X}$ and $\mathrm{Y}$ directions as given by

datum for latitude/longitude

spheroid for latitude/longitude

elevation at sample site, in feet; from 1:24,000

7.5' USGS quadrangle on which the site is located county that site is located in

date of sample collection at site

time of sample collection at site

brief sample location descriptor

brief sample site descriptor

brief description of mineral deposit(s) located

upstream of sample site

name of deposit(s) located upstream of site

mining district name

weather at time of sample collection

air temperature (Celsius) at time of collection 

Geol_Bedrock
memo
description of bedrock geology at the site
Contamination text
description of anthropogenic contamination at site
Other_Info
text
additional information about site

Table

WATSITEI

Fields:

Site_ID

Temp_C

Flow_Rate

Flow_Units

$\mathrm{pH}$

Conduct_uS/cm number

Turbidity_FTU number

Turbidity_Qual

Diss_O2_ppm

Water_Source

Type_of_Site

Water_Color

Water_Odor

Channel_Bed

Other_Notes

\section{Description}

text

number

number

text

number

text

number

text

text

text

text

text

text information relevant specifically to water sample sites

Field Type: Contents: sample site identifier (field is common to all tables)

water temperature at collection site, degrees Celsius

estimated water flow rate (ball-park estimate)

units of measurement for flow (gpm, gallons per

minute; cfs, cubic feet per second)

water $\mathrm{pH}$ at collection site

water conductivity at collection site, in

microsiemens per centimeter

turbidity of sampled water, formazine turbidity

units (equivalent to nephelometric turbidity units), collected for 2001 samples only

qualitative estimate of water turbidity

dissolved oxygen in water at collection site, in ppm

source of water samples collected

water sample site descriptor

color of sampled water

odor of sampled water

brief description of water channel bed

additional descriptive information for sample or site

\section{Tables containing geochemical analyses}

The following fields are common to all or most tables containing geochemical analyses:
Fields:
Field Type: Contents:
Site_ID
text
sample site identifier (field is common to all tables)
Field_No
text
Lab_No
text sample field number; this is the site identifier with applicable QA/QC suffix and sample media suffix; for example 96SA072DFA

Actual_Sample text
laboratory-assigned sample number; this is the sample record ID in the USGS National Geochemical Database description of actual sample analyzed, following sample preparation quality assurance/quality control information

For the following tables, geochemical analyses follow the common fields described above. Format for the geochemical analyses are as described above in the GEOCHEMICAL ANALYSES section. Except for the heavy mineral concentrate data, all geochemical analyses are given as numeric fields with a negative sign ("“-") replacing "less than" (“<”) qualifiers. For heavy 
mineral concentrates, the geochemical analyses are given as text fields because of the qualifiers $\mathrm{N}, \mathrm{L}$, and $\mathrm{G}$.

Table

WATANI

WATCATFA

WATCATRA

WATHG
Description

anion analyses, filtered/unacidified, refrigerated water

cation analyses, filtered/acidified water

cation analyses, unfiltered/acidified water

mercury analyses, filtered/preserved water

The following fields are unique to specific tables:

Table

WATFE2+

Fields:

Fe2+_PPM_CO

Fe2+_PPM_FLD number

Description

number
$\mathrm{Fe}^{2+}$ analyses, filtered/acidified water

Field Type: Contents:

ferrous iron by colorimetric method, analyzed in laboratory, parts per million, done on 1996 hot springs samples and Blackbird Creek only ferrous iron analyzed in field at collection site with CHEMetrics, Inc. colorimetric test kit, parts per million, done on all 2001 samples only
Table

WATALK

Fields:

Alk_PPM_TI

Alk_PPM_FLD number

Description

number alkalinity analyses, unfiltered/unacidified, refrigerated water

Field Type: Contents:

alkalinity by titration, analyzed in laboratory; parts

per million as $\mathrm{CaCO} 3$, done on 2001 samples

having field kit alkalinities of $25 \mathrm{ppm}$ or less

alkalinity analyzed in field at collection site with

CHEMetrics, Inc. titration kit, as parts per million

equivalent $\mathrm{CaCO}_{3}$; done on all 1996 and 2001

samples
Table

HMCONC

Fields:

Sieve_Size

Sample_Descr

Character

Source

Mineral_Scan
Description

heavy-mineral concentrate descriptive and analytical data

Field Type: Contents:

text

text

text

text

text sample sieve size as prepared in laboratory

brief sample description

character of sample: single grab or composite of several increments

sample collected from outcrop, float, alluvium, etc.

on-site hand lens examination of panned

concentrate

Geochemical analyses follow at this point.

Table

SEDIMENT

Fields:
Description

sediment descriptive and analytical data

Field Type: Contents: 


\begin{tabular}{|c|c|c|}
\hline Sample_Descr & text & brief sample description \\
\hline Character & text & $\begin{array}{l}\text { character of sample: single grab or composite of } \\
\text { several increments }\end{array}$ \\
\hline Source & text & sample collected from outcrop, float, alluvium, etc. \\
\hline Organic_Cont & text & relative organic content in sample collected \\
\hline Sieve_Size & text & sample sieve size as prepared in laboratory \\
\hline Stain_Alluv & text & $\begin{array}{l}\text { iron oxide or manganese oxide staining observed on } \\
\text { alluvium }\end{array}$ \\
\hline Geology_Alluv & text & geologic description of alluvium at sample site \\
\hline
\end{tabular}

\section{Table containing wildfire study fields}

Table

WILDFIRE

Fields:

Site_ID

2ndSite_ID

Sort_Top_to_Bottom number

Sort_Sites_Together number

Potential_Fire_Effects text

\section{Description}

text

text fields containing wildfire information and sorting codes

Field Type: Contents:

sample site identifier (field is common to all tables) secondary descriptive sample site ID, for Middle Fork (MF), Main Salmon (SA), and Panther Creek (PC), with creek name and year collected; DUPE indicates sample site duplicate sorting code for grouping 1996 samples together (values 1-83) and equivalent 2001 samples (values as above +100$)$ together, starting from the upper end of the river and working downstream; order is Middle Fork, then Salmon River, then Panther Creek; example: 2 is Sulphur Creek on the Middle Fork in 1996, 102 is same site in 2001; no entry for sample site duplicates or unique samples sort code for grouping 1996 and 2001 samples together next to one-another (1996 sample followed by equivalent 2001 sample); Middle Fork (values < 100), Main Salmon (values 101 to 122), and Panther Creek (values > 200); includes sample site duplicates and unique samples qualitative estimate of 2000 wildfire effects in drainage basin above site, from B. Rieffenberger; Sig, significant; Min, minimal; Dnb, did not burn; ?, unknown

\section{PHOTOGRAPHS}

Digital photographs were taken by R.G. Eppinger at each sample site in the 2001 study. Unfortunately, photographs were not taken at these sites in the initial 1996 study. The 2001 photographs are listed in Table 3 and provided as .PDF files. The filenames are the same as the sample site ID number. Multiple photographs from a given site are listed with a numeric suffix. For example, filename 01SA240.PDF is a photograph of the sample collection locality at site 01SA240, while filename 01SA254-2.PDF is the second of a series of photographs from site 
01SA254. Photographs were formatted as 3.75 in X 5 in, 150 dpi. All photograph files are located in the PHOTOS folder. 
Table 3. List of sample site photographs. [photographs are in the PHOTOS folder].

\begin{tabular}{|c|c|c|c|}
\hline $\begin{array}{l}\text { Sample Site } \\
\text { Number }\end{array}$ & Description & $\begin{array}{l}\text { Sample Site } \\
\text { Number }\end{array}$ & Description \\
\hline & Middle Fork Drainage & & \\
\hline $01 S A 240$ & Middle Fork above Sulphur Creek & $01 S A 272$ & Middle Fork above Waterfall Creek \\
\hline $01 S A 241$ & Sulphur Creek near mouth & 01SA273-1 & Waterfall Creek near mouth \\
\hline $01 S A 242$ & Elkhorn Creek near mouth & 01SA273-2 & Waterfall Creek near mouth \\
\hline $01 S A 243$ & Soldier Creek near mouth & $01 S A 274$ & Big Creek near mouth \\
\hline 01SA244 & Fire Island hot spring & $01 S A 275$ & Middle Fork above Papoose Creek \\
\hline $01 S A 245$ & $\begin{array}{l}\text { Middle Fork above Greyhound } \\
\text { Creek }\end{array}$ & 01SA276-1 & Papoose Creek near mouth \\
\hline 01 SA246 & Greyhound Creek near mouth & 01SA276-2 & Papoose Creek near mouth \\
\hline $01 \mathrm{SA} 247$ & Middle Fork above Rapid River & 01SA276-3 & Papoose Creek near mouth \\
\hline $01 \mathrm{SA} 248$ & Rapid River near mouth & $01 S A 277$ & Ship Island Creek near mouth \\
\hline $01 S A 249$ & Middle Fork above Lake Creek & $01 S A 278$ & Parrot Creek at mouth \\
\hline 01SA250-1 & $\begin{array}{l}\text { Pistol Creek looking downstream } \\
\text { from pack bridge near mouth }\end{array}$ & 01SA279 & Middle Fork above Stoddard Creek \\
\hline 01SA250-2 & $\begin{array}{l}\text { Pistol Creek looking upstream from } \\
\text { pack bridge near mouth }\end{array}$ & 01SA280 & Stoddard Creek near mouth \\
\hline 01SA250-3 & Pistol Creek pack bridge & $01 S A 281$ & Roaring Creek near mouth \\
\hline 01SA250-4 & Pistol Creek campsite & 01SA282-1 & Color Creek near mouth \\
\hline 01SA251 & Middle Fork above Indian Creek & 01SA282-2 & Color Creek near mouth \\
\hline $01 S A 252$ & Indian Creek near mouth & 01SA283 & Goat Creek near mouth \\
\hline 01SA254-1 & Little Soldier Creek at mouth & 01SA284 & $\begin{array}{l}\text { Middle Fork above Main Salmon } \\
\text { River }\end{array}$ \\
\hline 01SA254-2 & Little Soldier Creek at mouth & & Main Salmon Drainage \\
\hline 01 SA255 & Marble Creek near mouth & $01 S A 285$ & Kitchen Creek near mouth \\
\hline $01 S A 256$ & Middle Fork above Little Loon Creek & 01 SA286 & Butts Creek near mouth \\
\hline 01SA257-1 & Little Loon Creek at mouth & $01 S A 315$ & Corn Creek near mouth \\
\hline 01SA257-2 & Little Loon Creek at mouth & $01 S A 316$ & $\begin{array}{l}\text { Colson Creek about } 1 / 2 \mathrm{mi} \text { above } \\
\text { mouth }\end{array}$ \\
\hline 01SA258 & Middle Fork above White Creek & $01 S A 317$ & $\begin{array}{l}\text { Lake Creek at confluence with Main } \\
\text { Salmon }\end{array}$ \\
\hline 01SA259 & White Creek near mouth & 01SA318 & $\begin{array}{l}\text { Owl Creek about 1/4 mi above } \\
\text { mouth }\end{array}$ \\
\hline 01SA260 & Loon Creek near mouth & $01 S A 319$ & $\begin{array}{l}\text { Main Salmon below Cove Creek } \\
\text { bridge }\end{array}$ \\
\hline $01 S A 261$ & Loon Creek hot springs & 01SA320-1 & $\begin{array}{l}\text { Looking upstream, Main Salmon } \\
\text { about } 1 / 4 \text { mi above Panther Creek }\end{array}$ \\
\hline 01SA262 & Middle Fork above Norton Creek & 01SA320-2 & $\begin{array}{l}\text { Looking downstream, Main Salmon } \\
\text { about } 1 / 4 \text { mi above Panther Creek }\end{array}$ \\
\hline 01SA263 & $\begin{array}{l}\text { Norton Creek at mouth from across } \\
\text { Middle Fork }\end{array}$ & $01 \mathrm{SA321}$ & Pine Creek near mouth \\
\hline $01 S A 264$ & Grouse Creek near mouth & 01SA322 & Big Sheepeater Creek near mouth \\
\hline 01 SA265 & Middle Fork above Camas Creek & 01 SA323 & Boulder Creek near mouth \\
\hline 01 SA266 & Camas Creek near mouth & 01SA324 & Spring Creek near mouth \\
\hline $01 S A 267$ & Middle Fork above Sheep Creek & 01 SA325 & East Boulder Creek near mouth \\
\hline $01 S A 268$ & Sheep Creek at mouth & $01 S A 326$ & Squaw Creek near mouth \\
\hline 01SA269 & Brush Creek at mouth & $01 S A 327$ & $\begin{array}{l}\text { Indian Creek near mouth, along } \\
\text { Main Salmon River }\end{array}$ \\
\hline $01 S A 270$ & Middle Fork above Wilson Creek & $01 S A 328$ & Sage Creek near mouth \\
\hline $01 S A 271$ & Wilson Creek near mouth & 01SA329 & Moose Creek near mouth \\
\hline
\end{tabular}


Table 3. continued.

\begin{tabular}{|c|c|c|c|}
\hline $\begin{array}{l}\text { Sample Site } \\
\text { Number }\end{array}$ & Description & $\begin{array}{l}\text { Sample Site } \\
\text { Number }\end{array}$ & Description \\
\hline & Panther Creek Drainage & & \\
\hline 01SA287 & Fourth of July Creek near mouth & 01SA304-2 & $\begin{array}{l}\text { Looking downstream, Panther } \\
\text { Creek above Beaver Creek }\end{array}$ \\
\hline 01SA288 & Panther Cr. above Fourth of July Cr. & 01SA305 & Beaver Creek near mouth \\
\hline 01SA289 & Porphyry Creek near mouth & 01SA306-1 & Clear Creek near mouth \\
\hline 01SA290 & Musgrove Creek near mouth & 01SA306-2 & Clear Creek near mouth \\
\hline $01 \mathrm{SA} 291$ & Moyer Creek near mouth & 01SA306-3 & $\begin{array}{l}\text { New fine sediment with ash, Clear } \\
\text { Creek near mouth }\end{array}$ \\
\hline 01SA292 & $\begin{array}{l}\text { Panther Creek at McDonald Flat } \\
\text { Campground }\end{array}$ & 01SA307-1 & $\begin{array}{l}\text { Looking upstream, Panther Creek } \\
\text { above Garden Creek }\end{array}$ \\
\hline 01SA293 & Woodtick Creek near mouth & 01SA307-2 & $\begin{array}{l}\text { Looking downstream, Panther } \\
\text { Creek above Garden Creek }\end{array}$ \\
\hline $01 S A 294$ & Copper Creek near mouth & 01 SA308 & Garden Creek at mouth \\
\hline $01 S A 295$ & $\begin{array}{l}\text { Panther Creek above Blackbird } \\
\text { Creek }\end{array}$ & 01SA309-1 & $\begin{array}{l}\text { Big Creek hot springs, near mouth } \\
\text { of Panther Creek }\end{array}$ \\
\hline 01SA296-1 & Blackbird Creek near mouth & 01SA309-2 & $\begin{array}{l}\text { Big Creek hot springs, near mouth } \\
\text { of Panther Creek }\end{array}$ \\
\hline 01SA296-2 & Blackbird Creek near mouth & 01SA309-3 & $\begin{array}{l}\text { Big Creek hot springs, near mouth } \\
\text { of Panther Creek }\end{array}$ \\
\hline 01SA296-3 & Blackbird Creek near mouth & 01SA310-1 & $\begin{array}{l}\text { Blackbird Creek above mine and } \\
\text { freshwater impoundment pond }\end{array}$ \\
\hline 01SA296-4 & Blackbird Creek near mouth & 01SA310-2 & $\begin{array}{l}\text { Deer skeleton in ash-laden sedi- } \\
\text { ment, Blackbird Creek above mine } \\
\text { and freshwater impoundment pond }\end{array}$ \\
\hline 01SA296-5 & Blackbird Creek near mouth & $01 S A 311$ & $\begin{array}{l}\text { Big Deer Creek above confluence } \\
\text { with South Fork }\end{array}$ \\
\hline 01SA297-1 & $\begin{array}{l}\text { Panther Creek above Deep Creek } \\
\text { campground }\end{array}$ & $01 S A 312$ & $\begin{array}{l}\text { South Fork above confluence with } \\
\text { Big Deer Creek }\end{array}$ \\
\hline 01SA297-2 & $\begin{array}{l}\text { Ash \& charcoal in sediment,Panther } \\
\text { Creek above Deep Creek campgrnd }\end{array}$ & $01 S A 313$ & $\begin{array}{l}\text { South Fork above confluence with } \\
\text { Bucktail Creek }\end{array}$ \\
\hline 01SA298 & Deep Creek near mouth & 01SA314-1 & $\begin{array}{l}\text { Bucktail Creek above confluence } \\
\text { with South Fork }\end{array}$ \\
\hline 01SA299 & Napias Creek above mouth & 01SA314-2 & $\begin{array}{l}\text { Bucktail Creek above confluence } \\
\text { with South Fork }\end{array}$ \\
\hline 01SA300 & Big Jureano Creek near mouth & 01SA331-1 & $\begin{array}{l}\text { Panther Creek above Garden } \\
\text { Creek, after July } 2001 \text { Clear Creek } \\
\text { storm event }\end{array}$ \\
\hline 01SA301-1 & Big Deer Creek near mouth & 01SA331-2 & $\begin{array}{l}\text { Ash-laden fine sediment, Panther } \\
\text { Creek above Garden Creek, after } \\
\text { July } 2001 \text { Clear Creek storm event. }\end{array}$ \\
\hline 01SA301-2 & Big Deer Creek near mouth & 01SA332-1 & $\begin{array}{l}\text { Clear Creek near mouth, after July } \\
2001 \text { Clear Creek storm event, } \\
\text { compare with photo 01SA306- } 2 \text {. }\end{array}$ \\
\hline 01SA302 & $\begin{array}{l}\text { Panther Creek above Big Deer } \\
\text { Creek }\end{array}$ & 01SA332-2 & $\begin{array}{l}\text { Clear Creek near mouth, after July } \\
2001 \text { Clear Creek storm event }\end{array}$ \\
\hline 01SA303 & Trail Creek near mouth & 01SA332-3 & $\begin{array}{l}\text { Clear Creek near mouth, after July } \\
2001 \text { Clear Creek storm event, } \\
\text { compare with photo 01SA306-3 }\end{array}$ \\
\hline 01SA304-1 & $\begin{array}{l}\text { Looking upstream, Panther Creek } \\
\text { above Beaver Creek }\end{array}$ & 01SA332-4 & $\begin{array}{l}\text { Clear Creek near mouth, after July } \\
2001 \text { Clear Creek storm event, } \\
\text { compare with photo 01SA306-1 }\end{array}$ \\
\hline
\end{tabular}




\section{REFERENCES}

Adrian, B.M., Arbogast, B.F., Detra, D.E., and Mays, R.E., 1996, Direct-current arc emission spectrographic method for the semiquantitative analysis of geologic materials, in Arbogast, B.F., editor, 1996, Analytical methods manual for the Mineral Resource Surveys Program, U.S. Geological Survey: U.S. Geological Survey Open-File Report 96525, p. 130-143.

American Society for Testing and Materials, 2001a, Standard test methods for iron in water: American Society for Testing and Materials Annual Book of ASTM Standards 2001, section 11, Water and Environmental Technology, D 1068-96, p. 74-81.

American Society for Testing and Materials, 2001b, Standard test methods for acidity or alkalinity of water: American Society for Testing and Materials Annual Book of ASTM Standards 2001, section 11, Water and Environmental Technology, D 1067-92, p. 67-73.

Arbogast, B.F., editor, 1996, Analytical methods manual for the Mineral Resource Surveys Program, U.S. Geological Survey: U.S. Geological Survey Open-File Report 96-525, 248 p.

Brennan, T.S., Lehmann, A.K., O’Dell, I., and Tungate, A.M., 1996, Water resources data, Idaho water year 1996, volume 2, Upper Columbia River Basin and Snake River Basin below King Hill: U.S. Geological Survey Water-Data Report ID-96-2, 377 p.

Briggs, P.H., 1996, Forty elements by inductively coupled plasma-atomic emission spectrometry, in Arbogast, B.F., editor, 1996, Analytical methods manual for the Mineral Resource Surveys Program, U.S. Geological Survey: U.S. Geological Survey Open-File Report 96525, p. 77-94.

Briggs, P.H., 2002, The determination of twenty-seven elements in aqueous samples by inductively coupled plasma-atomic emission spectrometry, in Taggart, J.E., Jr., ed., Analytical methods for chemical analysis of geologic and other materials, U.S. Geological Survey Open-File Report 02-223, Chapter F. Available at http://pubs.usgs.gov/of/2002/ofr-02-0223/.

Briggs, P.H. and Fey, D.L., 1996, Twenty-four elements in natural and acid mine waters by inductively coupled plasma-atomic emission spectrometry, in Arbogast, B.F., editor, 1996, Analytical methods manual for the Mineral Resource Surveys Program, U.S. Geological Survey: U.S. Geological Survey Open-File Report 96-525, p. 95-101.

Brown, Z.A., and Curry, K.J., 2002a, Total sulfur by combustion, in Taggart, J.E., Jr., ed., Analytical methods for chemical analysis of geologic and other materials, U.S. Geological Survey Open-File Report 02-223, Chapter R. Available at http://pubs.usgs.gov/of/2002/ofr-02-0223/.

Brown, Z.A., and Curry, K.J., 2002b, Total sulfur by combustion, in Taggart, J.E., Jr., ed., Analytical methods for chemical analysis of geologic and other materials, U.S. Geological Survey Open-File Report 02-223, Chapter Q. Available at http://pubs.usgs.gov/of/2002/ofr-02-0223/.

d'Angelo, W.M., and Ficklin, W.H., 1996, Fluoride, chloride, nitrate, and sulfate in aqueous solution by chemically suppressed ion chromatography, in Arbogast, B.F., editor, 1996, Analytical methods manual for the Mineral Resource Surveys Program, U.S. Geological Survey: U.S. Geological Survey Open-File Report 96-525, p. 149-153.

Eppinger, Robert G., Briggs, Paul H., Brown, Zoe Ann, Crock, James G., Meier, Allen, Theodorakos, Peter M., and Wilson, Stephen A., 2001, Baseline geochemical data for stream sediment and surface water samples from Panther Creek, the Middle Fork of the 
Salmon River, and the Main Salmon River from North Fork to Corn Creek, collected prior to the severe wildfires of 2000 in central Idaho: U.S. Geological Survey Open-File Report 01-161, 20 p. Available at http://pubs.usgs.gov/of/2001/ofr-01-0161/.

Hach Company, 1996, DR/2010 spectrophotometer procedures manual: Loveland, Colorado, Hach Company, p. 337-340.

Hageman, P.L., 2002, Mercury in water by flow injection-cold vapor-atomic fluorescence spectrometry, in Taggart, J.E., Jr., ed., Analytical methods for chemical analysis of geologic and other materials, U.S. Geological Survey Open-File Report 02-223, Chapter N. Available at http://pubs.usgs.gov/of/2002/ofr-02-0223/.

Hageman, P.L. and Welsch, E.P., 1996, Arsenic, antimony, and selenium by flow injection or continuous-flow hydride generation atomic absorption spectrophotometry, in Arbogast, B.F., editor, 1996, Analytical methods manual for the Mineral Resource Surveys Program, U.S. Geological Survey: U.S. Geological Survey Open-File Report 96-525, p. 24-30.

Hageman, P.L., Brown, Z.A., and Welsch, E. 2002, Arsenic and selenium by flow injection or continuous flow-hydride generation-atomic absorption spectrometry, in Taggart, J.E., Jr., ed., Analytical methods for chemical analysis of geologic and other materials, U.S. Geological Survey Open-File Report 02-223, Chapter L. Available at http://pubs.usgs.gov/of/2002/ofr-02-0223/.

Horowitz, A.J., Demas, C.R., Fitzgerald, K.K., Miller, T.L., and Rickert, D.A., 1994, U.S. Geological Survey protocol for the collection and processing of surface-water samples for the subsequent determination of inorganic constituents in filtered water: U.S. Geological Survey Open-File Report 94-539, 57 p.

Lamothe, P.J., Meier, A.L., and Wilson, S.A., 2002, The determination of forty four elements in aqueous samples by inductively coupled plasma-mass spectrometry, in Taggart, J.E., Jr., ed., Analytical methods for chemical analysis of geologic and other materials, U.S. Geological Survey Open-File Report 02-223, Chapter H. Available at http://pubs.usgs.gov/of/2002/ofr-02-0223/.

Meier, A.L., Grimes, D.J., and Ficklin, W.H., 1994, Inductively coupled plasma mass spectrometry; a powerful analytical tool for mineral resource and environmental studies: U.S. Geological Survey Circular 1103-A, p. 67-68.

Motooka, J.M., 1996, Organometallic halide extraction for 10 elements by inductively coupled plasma-atomic emission spectrometry, , in Arbogast, B.F., editor, 1996, Analytical methods manual for the Mineral Resource Surveys Program, U.S. Geological Survey: U.S. Geological Survey Open-File Report 96-525, p102-108.

Motooka, J. M., and Grimes, D. J., 1976, Analytical precision of one-sixth order semiquantitative spectrographic analyses: U.S. Geological Survey Circular 738, 25 p.

O'Leary, R.M, 1996, Tellurium and thallium by flame atomic absorption spectrometry, in Arbogast, B.F., editor, 1996, Analytical methods manual for the Mineral Resource Surveys Program, U.S. Geological Survey: U.S. Geological Survey Open-File Report 96525, p. 37-41.

O'Leary, R.M, and Meier, A.L., 1996, Gold by flame or graphite furnace atomic absorption spectrometry, in Arbogast, B.F., editor, 1996, Analytical methods manual for the Mineral Resource Surveys Program, U.S. Geological Survey: U.S. Geological Survey Open-File Report 96-525, p. 31-36. 
O'Leary, R.M., Hageman, P.L., and Crock, J.G., 1996, Mercury in water, geologic, and plant materials by continuous flow-cold vapor-atomic absorption spectrometry, in Arbogast, B.F., editor, 1996, Analytical methods manual for the Mineral Resource Surveys Program, U.S. Geological Survey: U.S. Geological Survey Open-File Report 96-525, p. 42-50.

Papp, S.E., Aruscavage, P., and Brandt, E., 1996a, Ferrous oxide by potentiometric titration, in Arbogast, B.F., editor, 1996, Analytical methods manual for the Mineral Resource Surveys Program, U.S. Geological Survey: U.S. Geological Survey Open-File Report 96525 , p. 200-205.

Papp, S.E., Brandt, E., and Aruscavage, Pl, 1996b, Carbonate carbon by coulometric titration, in Arbogast, B.F., editor, 1996, Analytical methods manual for the Mineral Resource Surveys Program, U.S. Geological Survey: U.S. Geological Survey Open-File Report 96525, p. 60-66.

Peacock, T.R., Taylor, C.D., and Theodorakos, P.M., 1996, Stream-sediment sample preparation, in Arbogast, B.F., editor, 1996, Analytical methods manual for the Mineral Resource Surveys Program, U.S. Geological Survey: U.S. Geological Survey Open-File Report 96525, p. 7-10.

Taggart, J.E. Jr., editor, 2002, Analytical methods for chemical analysis of geologic and other materials, U.S. Geological Survey: U.S. Geological Survey Open-File Report 02-223. Available at http://pubs.usgs.gov/of/2002/ofr-02-0223/.

Taylor, C.D., and Theodorakos, P.M., 1996, Heavy-mineral concentrate preparation by heavy liquid and magnetic separation, in Arbogast, B.F., editor, 1996, Analytical methods manual for the Mineral Resource Surveys Program, U.S. Geological Survey: U.S. Geological Survey Open-File Report 96-525, p. 15-19

Theodorakos, P.M., 2002a, Fluoride, chloride, nitrate, and sulfate in aqueous solution utilizing autosuppression chemically suppressed ion chromatography, in Taggart, J.E., Jr., ed., Analytical methods for chemical analysis of geologic and other materials, U.S. Geological Survey Open-File Report 02-223, Chapter V. Available at http://pubs.usgs.gov/of/2002/ofr-02-0223/.

Theodorakos, P.M., 2002b, Ferrous iron (Fe2+) from 0 to $3.00 \mathrm{mg} / \mathrm{L}$ for water, wastewater, and seawater utilizing the HACH DR/2010 spectrophotometer method, in Taggart, J.E., Jr., ed., Analytical methods for chemical analysis of geologic and other materials, U.S. Geological Survey Open-File Report 02-223, Chapter W. Available at http://pubs.usgs.gov/of/2002/ofr-02-0223/.

Theodorakos, P.M., 2002c, Determination of total alkalinity using a Preset Endpoint (pH 4.5) autotitration system, in Taggart, J.E., Jr., ed., Analytical methods for chemical analysis of geologic and other materials, U.S. Geological Survey Open-File Report 02-223, Chapter E. Available at http://pubs.usgs.gov/of/2002/ofr-02-0223/. 


\section{APPENDIX}

Table A1. Limits of determination for stream sediment samples analyzed by 40-element inductively coupled plasma-atomic emission spectrometry, total extraction (ET).

\begin{tabular}{|c|c|c|c|c|c|}
\hline Element & \begin{tabular}{|c|} 
Lower \\
$\begin{array}{c}\text { Determination } \\
\text { Limit }\end{array}$ \\
\end{tabular} & \begin{tabular}{|c|} 
Upper \\
$\begin{array}{c}\text { Determination } \\
\text { Limit }\end{array}$
\end{tabular} & Element & \begin{tabular}{|c|}
$\begin{array}{c}\text { Lower } \\
\text { Determination } \\
\text { Limit }\end{array}$ \\
\end{tabular} & \begin{tabular}{|c|} 
Upper \\
$\begin{array}{c}\text { Determination } \\
\text { Limit }\end{array}$ \\
\end{tabular} \\
\hline \multicolumn{3}{|c|}{ Percent } & \multicolumn{3}{|c|}{ Parts Per Million } \\
\hline $\mathrm{Al}$, aluminum & 0.005 & 50 & Ga, gallium & 4 & 50,000 \\
\hline Ca, calcium & 0.005 & 50 & Ho, holmium & 4 & 5,000 \\
\hline Fe, iron & 0.02 & 25 & La, lanthanum & 2 & 50,000 \\
\hline $\mathrm{K}$, potassium & 0.01 & 50 & Li, lithium & 2 & 50,000 \\
\hline Mg, magnesium & 0.005 & 5 & Mn, manganese & 4 & 50,000 \\
\hline $\mathrm{Na}$, sodium & 0.005 & 50 & Mo, molybdenum & 2 & 50,000 \\
\hline P, phosphorus & 0.005 & 50 & $\mathrm{Nb}$, niobium & 4 & 50,000 \\
\hline Ti, titanium & 0.005 & 25 & Nd, neodymium & 9 & 50,000 \\
\hline \multicolumn{3}{|c|}{ Parts Per Million } & $\mathrm{Ni}$, nickel & 3 & 50,000 \\
\hline Ag, silver & 2 & 10,000 & $\mathrm{~Pb}$, lead & 4 & 50,000 \\
\hline As, arsenic & 10 & 50,000 & Sc, scandium & 2 & 50,000 \\
\hline $\mathrm{Au}$, gold & 8 & 50,000 & Sn, tin & 50 & 50,000 \\
\hline $\mathrm{Ba}$, barium & 1 & 35,000 & Sr, strontium & 2 & 15,000 \\
\hline $\mathrm{Be}$, beryllium & 1 & 5,000 & Ta, tantalum & 40 & 50,000 \\
\hline $\mathrm{Bi}$, bismuth & 50 & 50,000 & Th, thorium & 6 & 50,000 \\
\hline Cd, cadmium & 2 & 25,000 & U, uranium & 100 & 100,000 \\
\hline $\mathrm{Ce}$, cerium & 5 & 50,000 & V, vanadium & 2 & 30,000 \\
\hline Co, cobalt & 2 & 25,000 & $\mathrm{Y}$, yttrium & 2 & 25,000 \\
\hline Cr, chromium & 2 & 25,000 & Yb, ytterbium & 1 & 5,000 \\
\hline $\mathrm{Cu}$, copper & 2 & 15,000 & Zn, zinc & 2 & 15,000 \\
\hline Eu, europium & 2 & 5,000 & & & \\
\hline
\end{tabular}




\section{APPENDIX (cont.)}

Table A2. Limits of determination for selected elements in stream sediment samples analyzed by other methods. [values are in parts per million unless noted otherwise; EP, partial extraction 10-element inductively coupled plasma-atomic emission spectrometry; FA, fire assay atomic absorption spectrometry; $\mathrm{CV}$, cold-vapor atomic absorption spectrometry; $\mathrm{HY}$, hydride generation atomic absorption spectrometry; LE, Leco analyzer; CT, coulometric titration; TI, titration]

\begin{tabular}{|l|l|l|l|}
\hline \multicolumn{1}{|c|}{ Element } & Method & \multicolumn{1}{c|}{$\begin{array}{c}\text { Lower Determination } \\
\text { Limit }^{1}\end{array}$} & $\begin{array}{l}\text { Upper Determination } \\
\text { Limit }^{1,2}\end{array}$ \\
\hline Ag, silver & EP & 0.08 & 400 \\
\hline As, arsenic & EP & 1 & 6,000 \\
\hline Au, gold & EP & 0.1 & 1,500 \\
\hline Bi, bismuth & EP & 1 & 6,000 \\
\hline Cd, cadmium & EP & 0.05 & 500 \\
\hline Cu, copper & EP & 0.05 & 500 \\
\hline Mo, molybdenum & EP & 0.1 & 900 \\
\hline Pb, lead & EP & 1 & 6,000 \\
\hline Sb, antimony & EP & 1 & 6,000 \\
\hline Zn, zinc & EP & 0.05 & 500 \\
\hline Au, gold & FA & 0.005 & 10,000 \\
\hline Hg, mercury & CV & 0.02 & \\
\hline As, arsenic & HY & 0.6 & 20 \\
\hline Sb, antimony & HY & 0.6 & 20 \\
\hline Se, selenium & HY & 0.2 & 4 \\
\hline Te, tellurium & HY & 0.1 & \\
\hline TI, thallium & HY & 0.1 & $30 \%$ \\
\hline CTo, total carbon & LE & $0.05 \%$ & $50 \%$ \\
\hline CO2, carbonate & CT & $0.01 \%$ & $35 \%$ \\
\hline STo, total sulfur & LE & $0.05 \%$ & \\
\hline FeO, ferrous oxide & TI & $0.01 \%$ & \\
\hline
\end{tabular}

${ }^{1}$ Limits of determination shown here are nominal and limits may vary in the data files. The variability in limits of determination is due to variable sample weight used, dilution of the sample solution, instrumental interference correction, and slight changes in methodology over time.

${ }^{2}$ Samples containing concentrations greater than the upper limits of determination listed here were diluted and reanalyzed. 


\section{APPENDIX (cont.)}

Table A3. Limits of determination for nonmagnetic heavy-mineral concentrate samples analyzed by semiquantitative emission spectrography (ES).

\begin{tabular}{|c|c|c|c|c|c|}
\hline Element & $\begin{array}{l}\text { Lower } \\
\text { Determination } \\
\text { Limit }\end{array}$ & $\begin{array}{l}\text { Upper } \\
\text { Determination } \\
\text { Limit }\end{array}$ & Element & $\begin{array}{l}\text { Lower } \\
\text { Determination } \\
\text { Limit }\end{array}$ & $\begin{array}{l}\text { Upper } \\
\text { Determination } \\
\text { Limit }\end{array}$ \\
\hline \multicolumn{3}{|c|}{ Percent } & \multicolumn{3}{|c|}{ Parts Per Million } \\
\hline $\mathrm{Ca}$, calcium & 0.1 & 50 & Ge, germanium & 20 & 200 \\
\hline Fe, iron & 0.1 & 50 & La, lanthanum & 100 & 2,000 \\
\hline Mg, magnesium & 0.05 & 20 & Mn, manganese & 20 & 10,000 \\
\hline $\mathrm{Na}$, sodium & 0.5 & 10 & Mo, molybdenum & 10 & 5,000 \\
\hline $\mathrm{P}$, phosphorus & 0.5 & 20 & $\mathrm{Nb}$, niobium & 50 & 5,000 \\
\hline $\mathrm{Ti}$, titanium & 0.005 & 2 & Ni, nickel & 10 & 10,000 \\
\hline \multicolumn{3}{|c|}{ Parts Per Million } & $\mathrm{Pb}$, lead & 20 & 50,000 \\
\hline Ag, silver & 1 & 10,000 & Pd, palladium & 10 & 2,000 \\
\hline As, arsenic & 500 & 20,000 & Pt, platinum & 50 & 2,000 \\
\hline $\mathrm{Au}$, gold & 20 & 1,000 & Sb, antimony & 200 & 20,000 \\
\hline B, boron & 20 & 5,000 & Sc, scandium & 10 & 200 \\
\hline $\mathrm{Ba}$, barium & 50 & 10,000 & Sn, tin & 20 & 2,000 \\
\hline Be, beryllium & 2 & 2,000 & Sr, strontium & 200 & 10,000 \\
\hline $\mathrm{Bi}$, bismuth & 20 & 2,000 & Th, thorium & 200 & 5,000 \\
\hline Cd, cadmium & 50 & 1,000 & V, vanadium & 20 & 20,000 \\
\hline Co, cobalt & 20 & 5,000 & W, tungsten & 50 & 20,000 \\
\hline Cr, chromium & 20 & 10,000 & $\mathrm{Y}, \mathrm{yttrium}$ & 20 & 5,000 \\
\hline Cu, copper & 10 & 50,000 & $Z n$, zinc & 500 & 20,000 \\
\hline Ga, gallium & 10 & 10,000 & $\mathrm{Zr}$, zirconium & 20 & 2,000 \\
\hline
\end{tabular}

Table A4. Limits of determination for acidified water samples analyzed by inductively coupled plasma-atomic emission spectrometry (EW).

\begin{tabular}{|c|c|c|c|c|c|}
\hline Element & $\begin{array}{l}\text { Lower } \\
\text { Determination } \\
\text { Limit }^{1}\end{array}$ & $\begin{array}{l}\text { Upper } \\
\text { Determination } \\
\text { Limit }\end{array}$ & Element & $\begin{array}{l}\text { Lower } \\
\text { Determination } \\
\text { Limit }^{1}\end{array}$ & $\begin{array}{l}\text { Upper Determination } \\
\text { Limit }\end{array}$ \\
\hline \multicolumn{3}{|c|}{ Parts Per Million } & \multicolumn{3}{|c|}{ Parts Per Billion } \\
\hline Al, aluminum & 0.01 & 1,000 & Cr, chromium & 1 & 10,000 \\
\hline $\mathrm{Ca}$, calcium & 0.1 & 1,000 & Cu, copper & 1 & 10,000 \\
\hline $\mathrm{K}$, potassium & 0.1 & 1,000 & $\mathrm{Fe}$, iron & 20 & 10,000 \\
\hline Mg, magnesium & 0.1 & 1,000 & Li, lithium & 1 & 10,000 \\
\hline $\mathrm{Na}$, sodium & 0.1 & 1,000 & Mn, manganese & 1 & 10,000 \\
\hline \multirow{2}{*}{ Si, silicon } & 0.1 & 1,000 & Mo, molybdenum & 20 & 10,000 \\
\hline & & & Ni, nickel & 1 & 10,000 \\
\hline \multicolumn{3}{|c|}{ Parts Per Billion } & P, phosphorus & 100 & 10,000 \\
\hline Ag, silver & 1 & 10,000 & $\mathrm{~Pb}$, lead & 20 & 10,000 \\
\hline As, arsenic & 100 & 10,000 & Sb, antimony & 50 & 10,000 \\
\hline B, boron & 5 & 10,000 & Sr, strontium & 1 & 10,000 \\
\hline $\mathrm{Ba}$, barium & 1 & 10,000 & $\mathrm{Ti}$, titanium & 50 & 10,000 \\
\hline $\mathrm{Be}$, beryllium & 1 & 10,000 & V, vanadium & 1 & 10,000 \\
\hline Cd, cadmium & 1 & 10,000 & Zn, zinc & 1 & 10,000 \\
\hline Co, cobalt & 1 & 10,000 & & & \\
\hline
\end{tabular}

${ }^{1}$ Limits of determination shown here are nominal and limits may vary in the data files. The variability in limits of determination is due to variable sample weight used, dilution of the sample solution, and instrumental interference correction. 


\section{APPENDIX (cont.)}

Table A5. Limits of determination for anions in water samples determined by ion chromatography (IC).

\begin{tabular}{|l|l|l|}
\hline Anion & $\begin{array}{l}\text { Lower } \\
\text { Determination } \\
\text { Limit }\end{array}$ & $\begin{array}{l}\text { Upper } \\
\text { Determination } \\
\text { Limit }\end{array}$ \\
\hline \multicolumn{3}{|c|}{ Parts Per Million } \\
\hline $\mathbf{C l}^{-}$, chloride & 0.08 & 4 \\
\hline $\mathbf{F}^{\text {, fluoride }}$ & 0.08 & 2 \\
\hline $\mathrm{NO}_{3}{ }^{-}$, nitrate & 0.08 & 10 \\
\hline $\mathbf{S O}_{4}{ }^{2-}$, sulfate & 0.1 & 20 \\
\hline
\end{tabular}

${ }_{1}$ Samples containing concentrations greater than the upper limits of determination listed here were diluted and re-analyzed. 
Table A6. Limits of determination for water samples analyzed by inductively coupled plasma-mass spectrometry (MW).

\begin{tabular}{|c|c|c|c|}
\hline Element & $\begin{array}{l}\text { Lower } \\
\text { Determination } \\
\text { Limit }^{1}\end{array}$ & Element & $\begin{array}{l}\text { Lower } \\
\text { Determination } \\
\text { Limit }{ }^{1}\end{array}$ \\
\hline \multicolumn{2}{|c|}{ Parts per million (ppm) } & \multicolumn{2}{|c|}{ Parts per billion (ppb) } \\
\hline Al, aluminum & 0.2 & La, lanthanum & 0.01 \\
\hline Ca, calcium & 0.05 & Li, lithium & 0.1 \\
\hline K, potassium & 0.0005 & Mn, manganese & 0.01 \\
\hline Mg, magnesium & 0.01 & Mo, molybdenum & 0.02 \\
\hline $\mathrm{Na}$, sodium & 0.01 & Nb, niobium & 0.02 \\
\hline Si, silicon & 0.23 & Nd, neodymium & 0.01 \\
\hline $\mathrm{SO}_{4}{ }^{2-}$, sulfate & 0.3 & Ni, nickel & 0.1 \\
\hline \multicolumn{2}{|c|}{\begin{tabular}{|c|} 
Parts per billion (ppb) \\
\end{tabular}} & P, phosphorus & 1 \\
\hline Ag, silver & 0.01 & $\mathrm{~Pb}$, lead & 0.05 \\
\hline As, arsenic & 0.2 & Pr, praseodymium & 0.01 \\
\hline Au, gold & 0.01 & Rb, rubidium & 0.01 \\
\hline $\mathrm{Ba}$, barium & 0.1 & Re, rhenium & 0.02 \\
\hline Be, beryllium & 0.05 & Sb, antimony & 0.02 \\
\hline $\mathrm{Bi}$, bismuth & 0.01 & Se, selenium & 0.2 \\
\hline Cd, cadmium & 0.02 & Sm, samarium & 0.01 \\
\hline Ce, cerium & 0.01 & Sn, tin & 0.05 \\
\hline Co, cobalt & 0.02 & Sr, strontium & 0.02 \\
\hline Cr, chromium & 0.1 & Ta, tantalum & 0.02 \\
\hline Cs, cesium & 0.01 & Tb, terbium & 0.005 \\
\hline Cu, copper & 0.2 & Te, tellurium & 0.1 \\
\hline Dy, dysprosium & 0.005 & Th, thorium & 0.03 \\
\hline Er, erbium & 0.005 & TI, thallium & 0.05 \\
\hline Eu, europium & 0.005 & Tm, thulium & 0.005 \\
\hline $\mathrm{Fe}$, iron & 1 & U, uranium & 0.005 \\
\hline Ga, gallium & 0.02 & V, vanadium & 0.1 \\
\hline Gd, gadolinium & 0.005 & W, tungsten & 0.02 \\
\hline Ge, germanium & 0.02 & Y, yttrium & 0.01 \\
\hline Hf, hafnium & 0.05 & Yb, ytterbium & 0.01 \\
\hline Ho, holmium & 0.005 & Zn, zinc & 0.5 \\
\hline In, indium & 0.01 & $\mathrm{Zr}$, zirconium & 0.05 \\
\hline
\end{tabular}

${ }^{1}$ Limits of determination shown here are nominal and limits may vary in the data files. The variability in limits of determination is due to variable sample weight used, dilution of the sample solution, and instrumental interference correction. Upper limits of determination are not shown because samples with high concentrations were diluted and re-analyzed. 